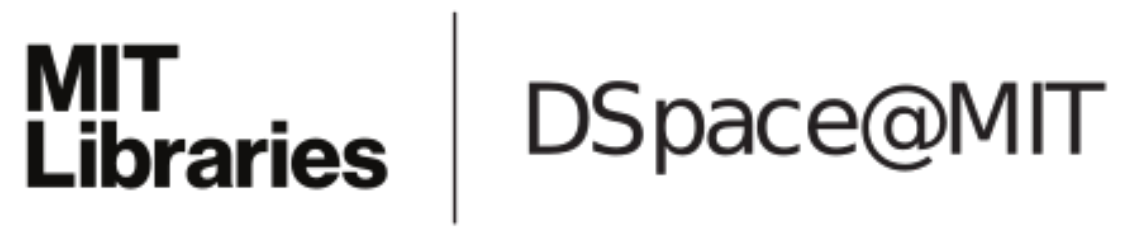

\author{
MIT Open Access Articles
}

The Political Economy of Gasoline
Taxes: Lessons from the Oil Embargo

The MIT Faculty has made this article openly available. Please share how this access benefits you. Your story matters.

Citation: Knittel, Christopher R. “The Political Economy of Gasoline Taxes: Lessons from the Oil Embargo." Tax Policy and the Economy 28, 1 (January 2014): 97-131 (c) 2014 National Bureau of Economic Research

As Published: http://dx.doi.org/10.1086/675589

Publisher: University of Chicago Press

Persistent URL: http://hdl.handle.net/1721.1/120703

Version: Final published version: final published article, as it appeared in a journal, conference proceedings, or other formally published context

Terms of Use: Article is made available in accordance with the publisher's policy and may be subject to US copyright law. Please refer to the publisher's site for terms of use. 


\title{
The Political Economy of Gasoline Taxes: Lessons from the Oil Embargo
}

\author{
Christopher R. Knittel, MIT and NBER
}

\section{Executive Summary}

From 1864 to 1972 , the real price of oil fell by, on average, over $1 \%$ per year. This trend dramatically broke when prices for crude increased by over $650 \%$ from 1972 to 1980. Policymakers adopted several policies designed to keep oil prices in check and reduce consumption. Missing from these policies were taxes on either oil or gasoline, prompting a long economics literature documenting the inefficiencies of these alternative policies. In this chapter, I review the policy discussion related to the transportation sector that occurred during the time through the lens of the printed press. In doing so, I pay particular attention to whether gasoline taxes were "on the table," as well as how consumers viewed the inefficient set of policies that were ultimately adopted. The discussions at the time suggest that meaningful changes in gasoline taxes were on the table; the public discussion seemed to be much greater than it is today. Some in Congress and many presidential advisors in the Nixon, Ford, and Carter administrations supported and proposed gasoline taxes. The main roadblocks for taxes were Congress and the American people. Polling evidence at the time suggests that consumers preferred price controls and rationing and vehicle taxes over higher gasoline taxes or letting gasoline prices clear the market. Given the saliency of rationing and vehicle taxes, it seems difficult to argue that these alternative policies were adopted because they hide their true costs.

Rejecting a stiff (probably 30 or 40 cent) increase in the gasoline tax may have been the president's most fateful energy decision. It relieved pressure on the automobile industry to break radically with its past: to produce a basic, simple, fuel-efficient car. Shorn of many of today's common accessories, such a car would give good fuel mileage, but less power and comfort than current automobiles. It would be intended primarily for transportation, not ego gratification, sex appeal, or even driving pleasure.

Washington Post, January 31, 1975

Can you imagine how much better off we'd be if President Ford had taken bold action (of passing a gasoline tax)?

Carter official, January 1980 


\section{Introduction}

By the end of 1972, things were great for oil. Prices were on a steady downward trend, falling on average by over $1 \%$ per year from 1861 to 1972; coal was giving way to oil as a fuel for electricity generation; and, vehicle ownership was expanding. Figure 1 shows oil prices from 1861 to 1972 . Real prices peaked in 1864 at $\$ 115.45$ per barrel and trended downward reaching a low point of $\$ 10.42$ per barrel in 1970 .

The drop in real oil prices coincides with increases in US oil consumption. Figure 2 plots consumption from 1875 to 2011. Consumption increased dramatically from 0.011 quadrillion BTUs (quads) in 1875 to nearly 35 quads in 1973. The introduction of the Ford Model T at the end of 1908 sparked a new use for petroleum. Vehicle ownership rose sharply until the Great Depression, but then appears to have continued on the pre-Great Depression trend after World War II (figure 3). Concerns about local pollution in the 1960s prompted shifts away from coal-fired electricity plants to oil-fired plants. The share of electricity generation coming from oil increased from roughly 6\% in 1960 to over $16 \%$ by 1973 (figure 4). By the early 1970s, it was clear that the United States was consuming more and more oil, but at the same time, oil expenditures as a fraction of gross domestic product (GDP) were extremely low-hovering at levels below $2 \%$ (figure 6).

The picture was very different by the end of 1973. In October of 1973 the members of the Organization of Arab Petroleum Exporting Countries (OPEC) announced a US oil embargo. The embargo, partly in retaliation for the US support of Israel during the Yom Kippur War, lasted through March of 1974. World oil prices rose sharply to an average of \$52.85 (in 2011 dollars) during 1974 and the United States spent over $\$ 300$ billion on oil, nearly 7\% of GDP. Expenditures on oil imports exceeded $2 \%$ of GDP.

Prices stabilized at these higher levels until 1979 when a second oil shock occurred in the wake of the Iranian Revolution. Protests in Iran hampered oil production and led to the suspension of Iranian oil exports. With Iranian production accounting for roughly $10 \%$ of world oil production, these disruptions had a large effect on prices. This was followed by the Iran-Iraq War which lowered production in both countries. Figure 5 shows production for the top five oil producers in the region. Production in Iran fell from roughly six million barrels per day (mmbd) prior to 1978 to below $1.5 \mathrm{mmbd}$ during 1980 and 1981 (world production hovered around $60 \mathrm{mmbd}$ during this time). Iraqi produc- 


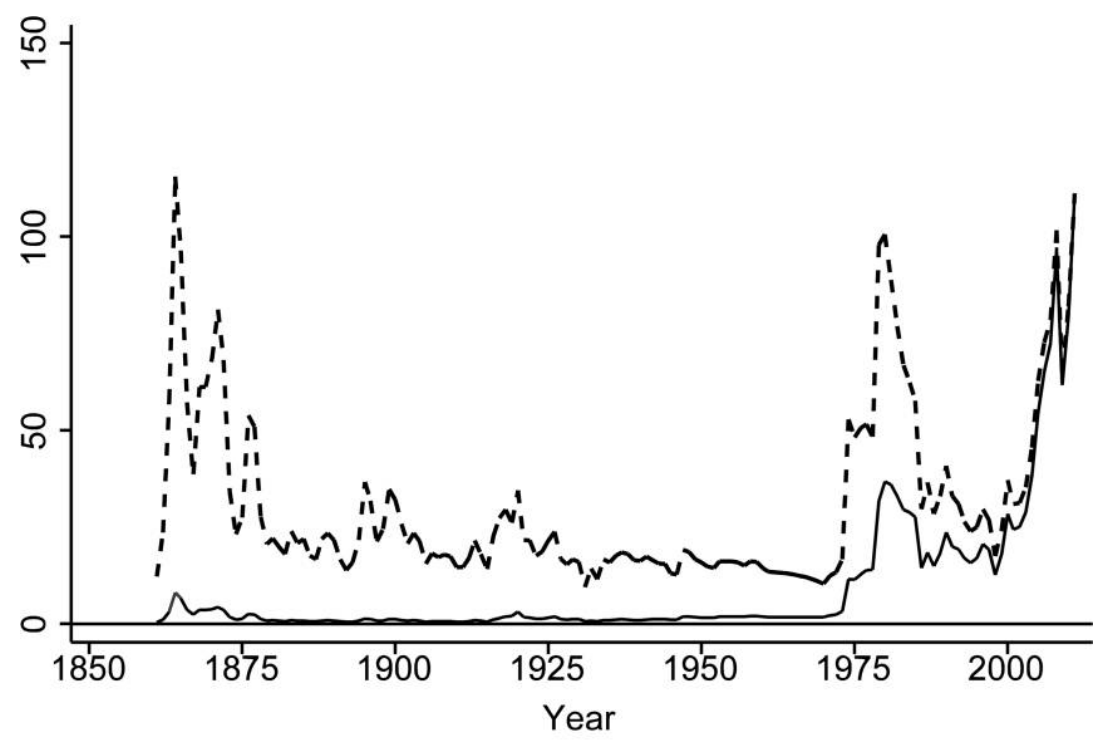

\section{Price - - - - Real Price}

Fig. 1. Oil prices from the 1800 s to 2011

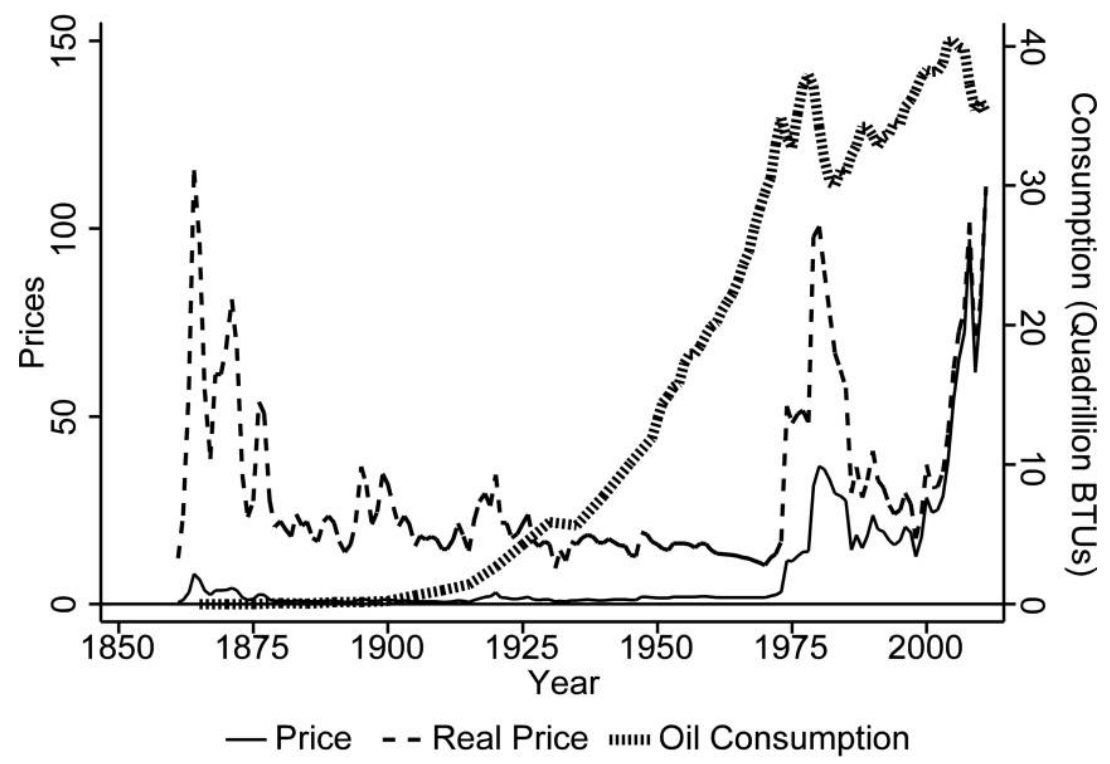

Fig. 2. Oil prices and consumption 


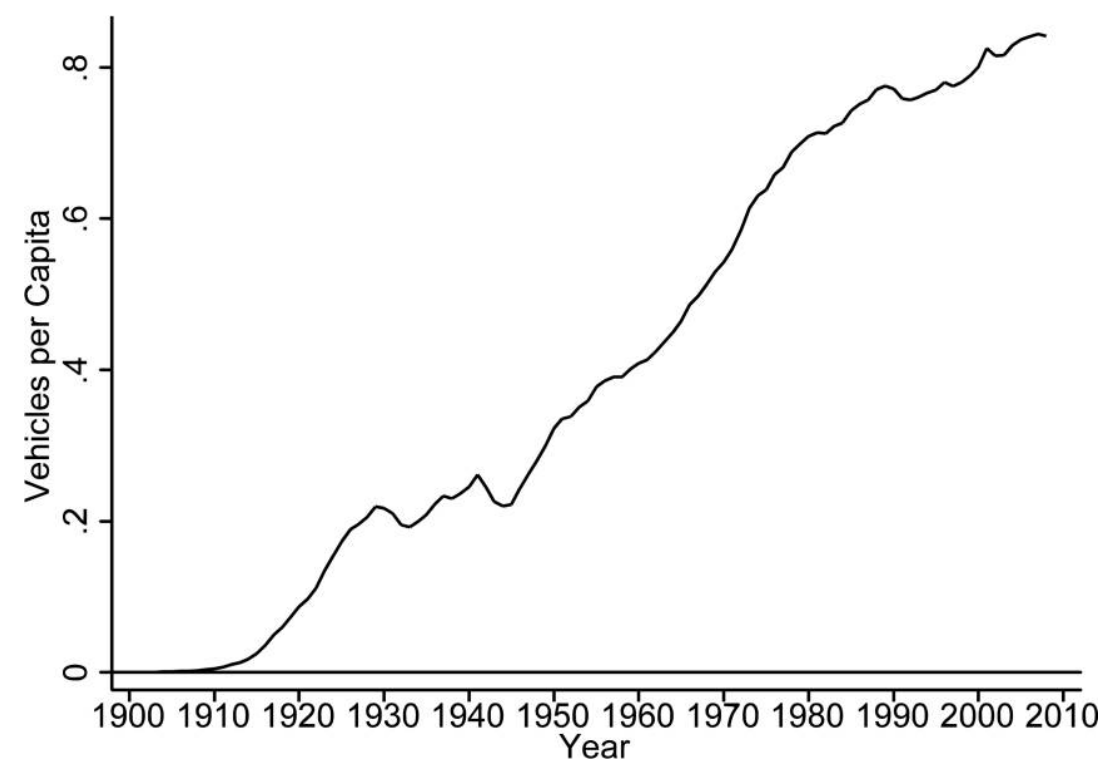

Fig. 3. Vehicles per capita

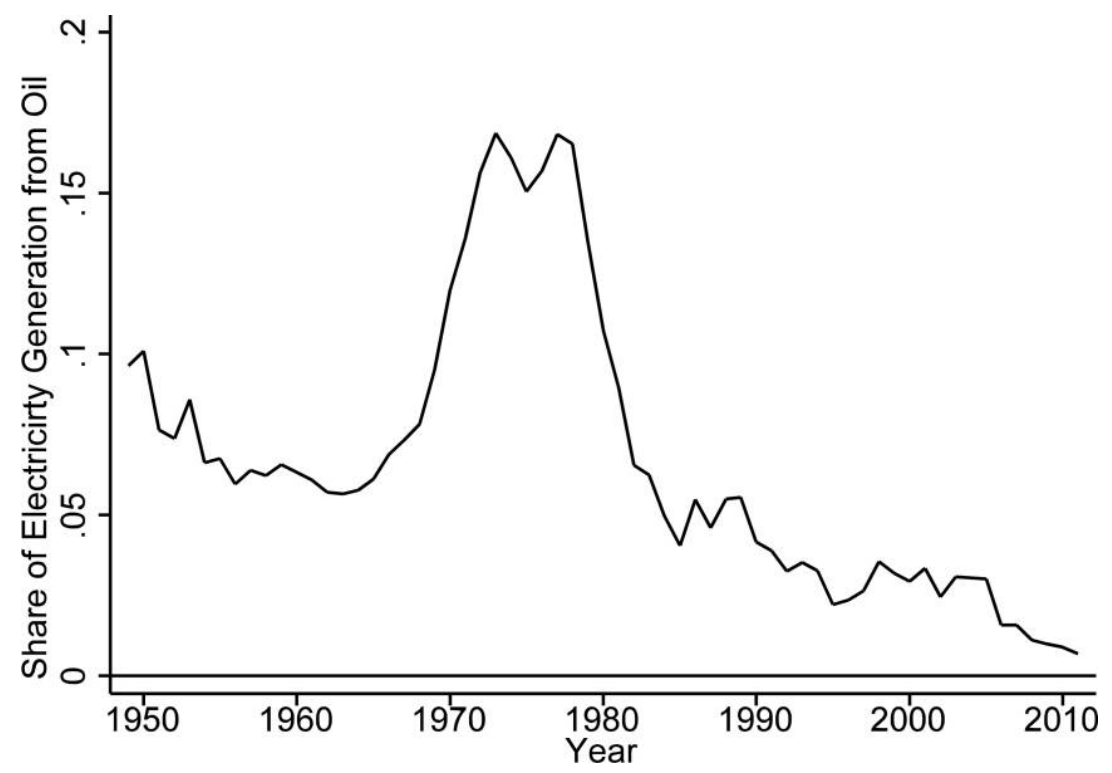

Fig. 4. Share of electricity generation coming from oil 


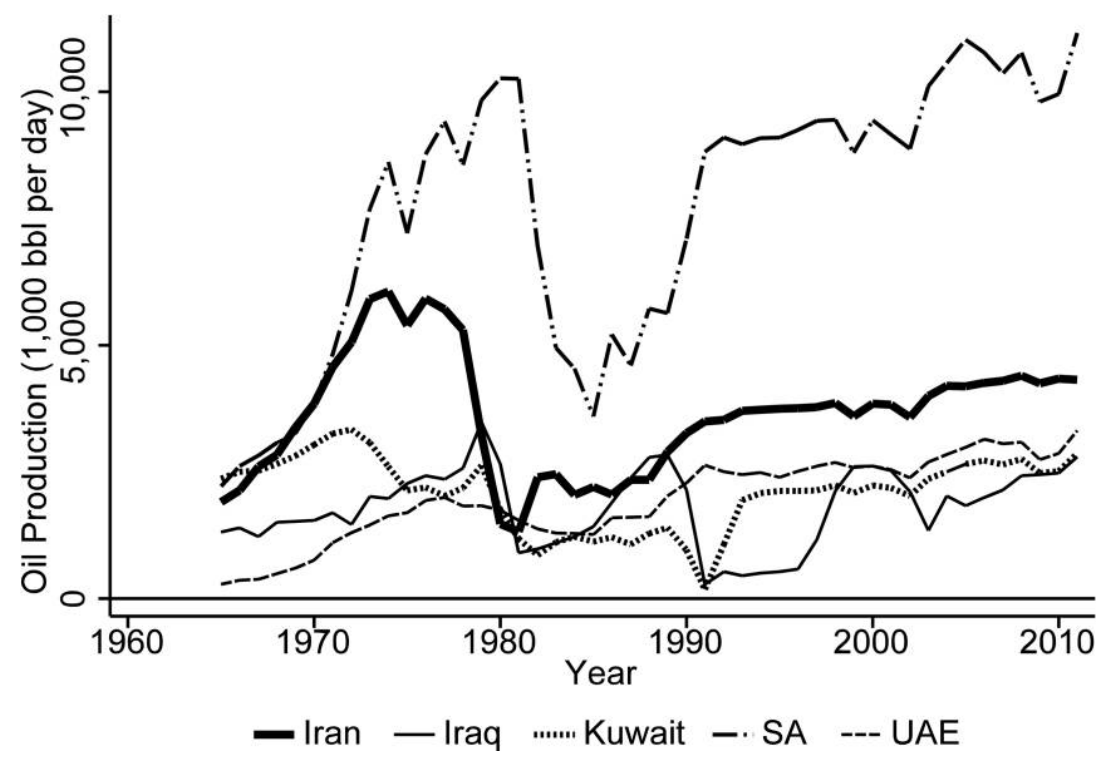

Fig. 5. Oil production for the top five oil producing states in the Middle East

tion fell below one mmbd in 1981 and 1982 from a peak of nearly 3.5 mmbd in 1979.

Oil prices peaked at over $\$ 100$ per barrel in real terms (2011 dollars) in 1980; US oil outlays exceeded 10\% of GDP in both 1979 and 1980 (figure 6). Perhaps more importantly, spending on oil imports exceeded $4.5 \%$ of US GDP in 1980.

While prices began to fall after 1980, the events from 1973 to 1980 made it clear that oil prices could be volatile and events in a single country, or a small group of organized countries, could have huge consequences on prices and macroeconomic activity.

Many pointed to the increases in oil imports as the major issue. Figure 7 plots consumption and the share of consumption coming from imports from 1960 onward. The import share began to rise rapidly in the late 1960s; US imports increased from 18.5\% in 1960 to over 36\% in 1973.

Oil imports drew the attention of policymakers even before the embargo. The Eisenhower administration established the Mandatory Oil Import Quota Program (MOIP) in 1959. MOIP put limits on crude oil and refined product imports, and gave preferential treatment to oil imports from Canada and Mexico. ${ }^{1}$ In April of 1972, Secretary of State John N. Irwin testified in front of the House Interior Committee, stating: 


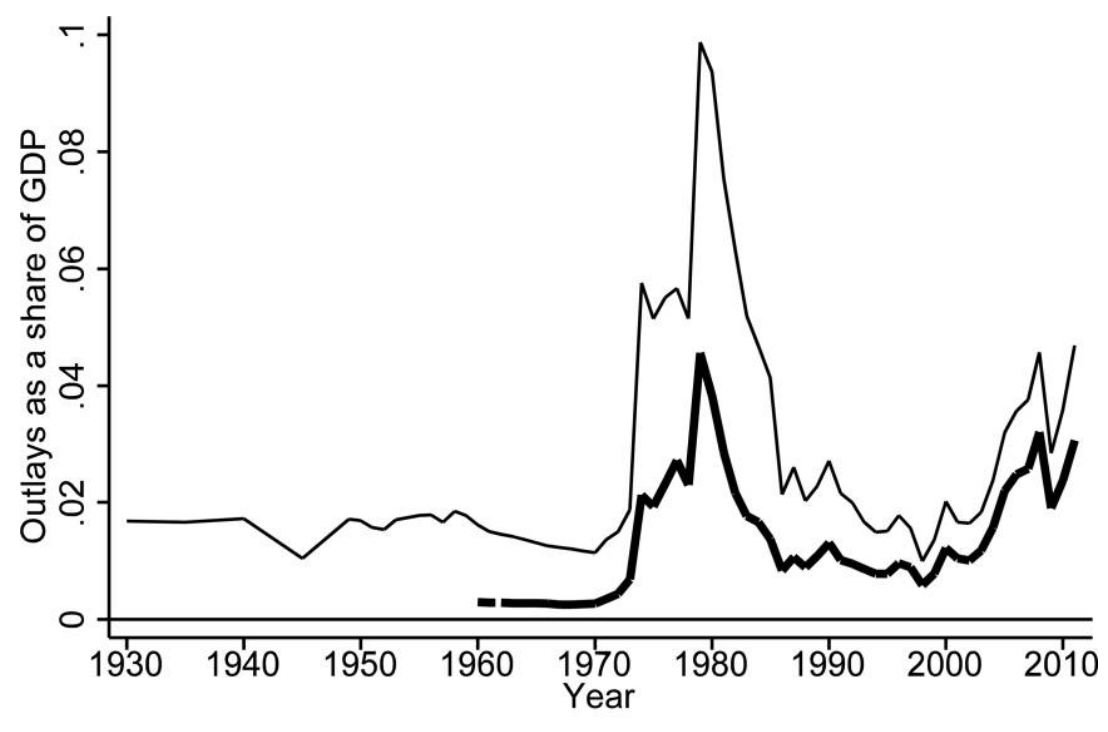

Fig. 6. National petroleum outlays as share of GDP

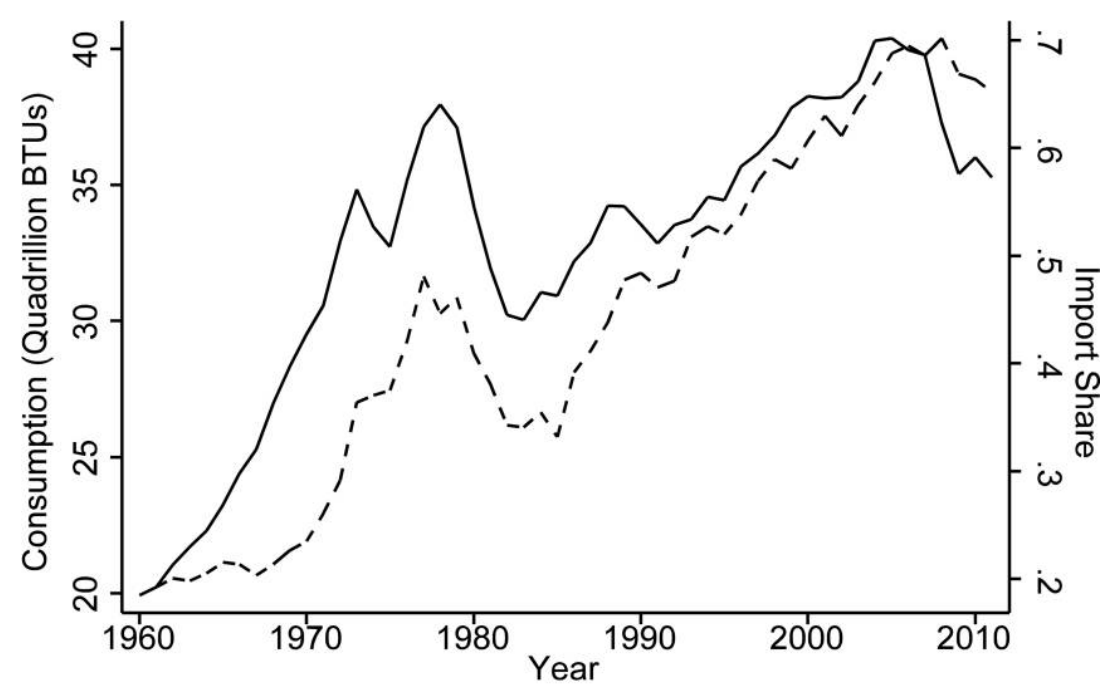

- Oil Consumption - - Import Share

Fig. 7. Consumption and import share 
"Isn't it self-evident that if the United States is dependent on the twothird to three-fourths of the world oil supply (in Middle East countries) we would be hard-pressed to resist their ultimatum that we keep hands off Israel? It would be a problem."2 Speaking in front of the House Foreign Affairs Subcommittee in October of 1972, James Atkins, a State Department oil expert, said: "We believe that the first priority of the United States is to limit its increasing reliance on imported supplies of oil.... We believe that the foreign policy pitfalls of an excessive reliance on important energy are too serious to risk. ${ }^{\prime 3}$ Indeed, the 1973 embargo was not the first embargo. In June of 1967 several Middle East countries limited shipments to the United States and the United Kingdom, but only Syria stopped all oil exports. Given the low cost of shipping oil, these actions had little influence on oil prices.

It isn't completely clear on economic efficiency grounds that policymakers needed to react to the oil crises; the public debate typically was not couched in terms of market failures such as externalities. But, given the reliance of the US economy on oil consumption, one could argue that consumers did not internalize the costs of oil consumption associated with its affect on macroeconomic activity and energy security. ${ }^{4}$ There was little question that policymakers felt a need to react.

The first response from these events was to strengthen price controls on oil, prompting the need for rationing rules, but long gasoline lines and shortages still occurred. The speed limit on highways was reduced to 55 miles per hour. Corporate Average Fuel Economy (CAFE) Standards and gas guzzler taxes were subsequently adopted. Absent from these policies was a gasoline tax. Indeed, price controls on both oil and gasoline pushed prices below equilibrium levels. The reliance on alternatives to Pigouvian taxes led to a long literature in economics estimating the inefficiencies of these alternative policies. (See, for example, Fischer, Harrington, and Parry 1982; Jacobsen forthcoming; Holland, Hughes, and Knittel 2009; Holland et al. 2010; and Sallee 2011.)

In this chapter, I review the policies adopted as a response to the shocks. Next, I compare fuel consumption in the United States with a large set of countries both before and after the shocks. Finally, I review the policy discussion related to the transportation sector that occurred during the time through the lens of the printed press and polling. In doing so, I pay particular attention to whether gasoline taxes were "on the table," as well as how consumers reacted to the inefficient set of policies ultimately adopted.

Discussions at the time suggest that meaningful changes in gasoline taxes as a way to reduce consumption were on the table; the public 
discussion seemed to be much greater than it is today. This is despite the fact that price controls were clearly working against such taxes. Some in Congress and many presidential advisors in the Nixon, Ford, and Carter administrations supported and proposed gasoline taxes. Presidents Nixon and Carter supported higher gasoline taxes, while President Ford did not. However, Ford was a staunch advocate of decontrolling oil prices, and therefore understood the incentives that higher prices would bring. ${ }^{5}$ The main roadblocks for taxes were Congress and the American people. Polling evidence at the time suggests that consumers preferred price controls and rationing over higher gasoline taxes. They also preferred taxes on low fuel economy vehicles over increases in gasoline prices. Given the saliency of the costs associated with rationing gasoline consumption, namely, the potential for queueing, it seems difficult to argue that these alternative policies were adopted because they hide their true costs. This would seem to suggest one of two possibilities, or a combination of the two: (1) we tend to overstate the value of people's time for activities such as refueling, and (2) concerns about the regressivity of policies such as gasoline taxes outweigh their efficiency gain. ${ }^{6}$

\section{Policy Responses}

The United States enacted a variety of policies designed to reduce consumption and limit price impacts. The discussion at the time centered around a desire for policymakers to keep oil and gasoline expenditures down and to limit "windfall" profits for domestic oil companies. In this section, I discuss the policies adopted.

\section{A. Supply-Side Policies}

Prior to the oil embargo, oil and gasoline markets were already stressed. The MOIP reduced oil imports, and President Nixon instituted price controls for oil beginning in 1971 as part of a large program controlling prices. These actions led to oil shortages in 1971 and 1972 and long lines for gasoline in 1972. The 1971 shortage and the expectation of a shortage in 1972 prompted Nixon to lift import controls for Canadian oil.

The imposition of price controls, and their popularity in 1971 likely laid the groundwork for the policies adopted during the oil crises and policymakers' resistance to taxes. While firms and labor unions tended to oppose price (and wage) controls, they appeared to be popular among consumers (and even some academic economists). ${ }^{7}$ A Harris 
Table 1

Harris Survey Results Related Price Controls, April 6, 1972

\begin{tabular}{lccc}
\hline Month & \%More Good than Harm & \%More Harm than Good & \% Not Sure \\
\hline March 1972 & 47 & 28 & 25 \\
January & 48 & 27 & 25 \\
September 1971 & 53 & 23 & 24 \\
August & 47 & 29 & 24 \\
May & 32 & 40 & 28 \\
March & 34 & 37 & 29 \\
January & 35 & 39 & 26 \\
\hline
\end{tabular}

poll in early 1972 found that respondents, by a 53 to 23 margin, believed Nixon's price controls were doing "more good than harm. ${ }^{\prime 8}$ In fact, the description of the poll results point to concerns among respondents that Nixon was being too flexible on prices.

The time series of approval ratings for Nixon's economic policies also points to the popularity of his price control policies. Table 1 shows a time series of a Harris poll asking: "Do you feel the economic policies of the Nixon administration are doing more good than harm or more harm than good?" Nixon's approval rating jumped up right when price controls were adopted and hovered near $50 \%$, while tending to hover around $30 \%$ prior to the controls.

The oil embargo struck in October of 1973. In November of 1973, Nixon signed the Emergency Petroleum Allocation Act which further regulated oil prices. The Act created a two-tiered pricing system. "Old oil" — those wells drilled before 1973-had a price ceiling of $\$ 5.25$ a barrel (\$19.44 in 2011 dollars). "New oil" was defined as oil from wells that began operation after 1972, or production from old wells above the wells' 1972 production levels. The price of new oil could be as high as $\$ 11$ per barrel (\$40.74 per barrel in 2011 dollars), close to the world price at the time of roughly $\$ 12$ per barrel (\$44.44). ${ }^{9}$ The Act also extended price controls for refined products. The two-tiered pricing structure created large rent transfers. Those refineries that had access to old oil were more profitable than those relying on imports or new oil. In response to this, "old oil entitlements" were issued beginning in 1974 to equate the benefits, more or less, of old oil across refineries. To do this, refineries that used more old oil had to buy entitlements from refineries that consumed more imported oil.

Shortages in 1974 led to a nationwide odd-even rationing program. Vehicles with license plates ending in an odd number could purchase 
gas on odd days; those with even-numbered license plates could purchase fuel on even days. To even out access, everyone could purchase gasoline on the 31st. Given the infrequency in which vehicles refuel, it isn't clear whether odd-even rationing reduced consumption.

Ford entered office in August of 1974. Ford pushed for decontrol of oil prices, but Congress rejected his proposals. The Energy Policy and Conservation Act (EPCA) of 1975 (Public Law 94-163) was a compromise, of sorts. The Act, which lasted 40 months, reduced price controls for domestic oil, reversed a $\$ 2$ tariff on oil imports (discussed below), and created a maximum average price for domestic oil. Under the Act, average oil prices would fall from their current level of $\$ 8.75$ a barrel to $\$ 7.66$, and be allowed to grow up to $10 \%$ per year, at the discretion of the president, until February of 1977. After this date, Congress could stop any increase in oil prices above the rate of inflation. ${ }^{10}$ The Act was later amended in September of 1976 to allow prices to increase by $10 \%$ a year for the entire 40-month period. The Act also required decreases in crude prices be passed through, in their entirety, at "all levels of distribution from the producer through the retail level ..."

Ford reluctantly signed the EPCA, stating: "This legislation is by no means perfect. It does not provide all the essential measures that the Nation needs to achieve energy independence as quickly as I would like. However, after balancing the inadequacies and the merits, I have concluded that this bill is in the national interest and should be enacted into law." His reluctant support came from the fact that the Act gradually phased out price controls: "The bill seeks to lower retail prices in the short term and runs the risk of creating a false impression that we can have all the energy we want at cheaper prices. But over time, this legislation removes controls and should give industry sufficient incentive to explore, develop, and produce new fields in the Outer Continental Shelf, Alaska, and potential new reserves in the lower 48 states. I fully intend to use the flexibility which is granted to me by this legislation to expedite the decontrol of crude oil in order to increase domestic production. I do not expect the Congress to stand in the way of such actions."11

The second oil crisis led to the large shortages of gasoline. Despite resistance from Congress and consumer groups, Carter began phasing out price controls on oil as soon as EPCA allowed (June of 1979). ${ }^{12}$ Carter also increased the allotted markup for refining in early 1980, increasing gasoline prices independent of the change in crude prices. ${ }^{13}$

Pressure from the Department of Energy (DOE) and the announce- 


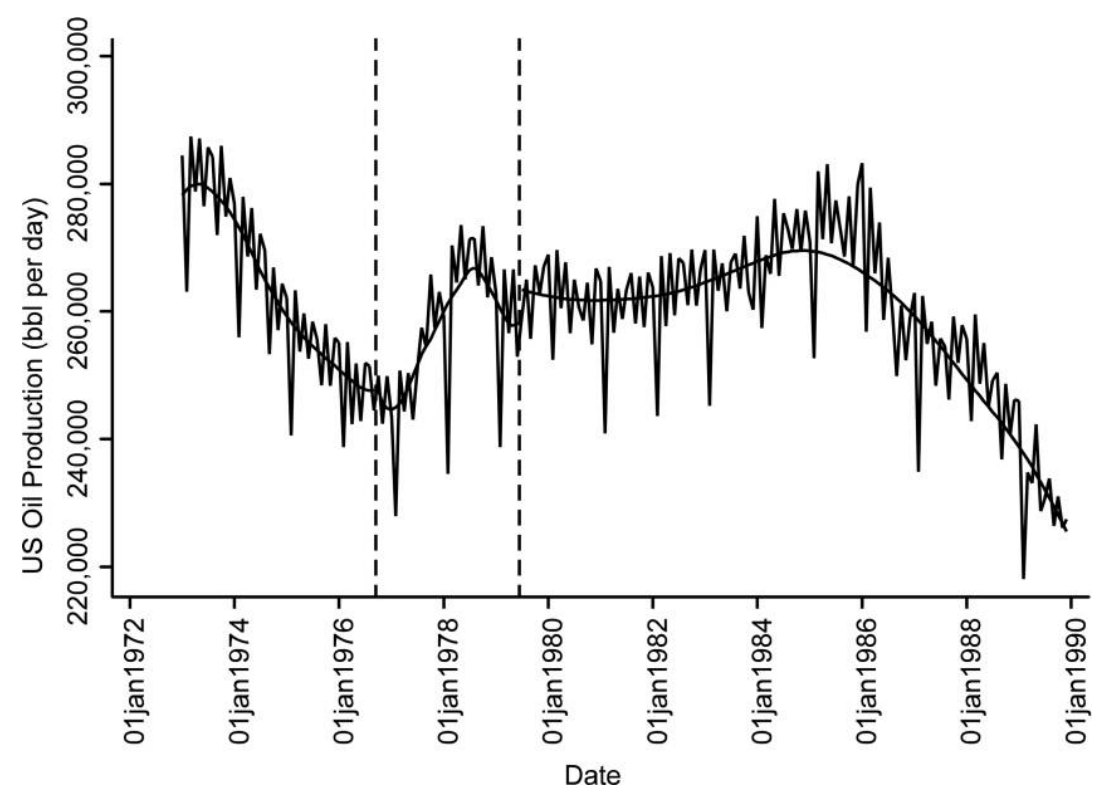

Fig. 8. Monthly US production of oil

ment that price controls would be relaxed during 1979 may have exacerbated shortages. Verleger (1979) documents that while the DOE called on refineries to build up inventories of gasoline at the beginning of the year, they also called on refineries to build up inventories of distillate fuels in April, leading to more crude oil being used to make fuel for winter heating. In addition, the price control system may have led to an incentive to withhold gasoline, at least on the margin. The price of gasoline was based on the previous month's crude acquisition costs. Depending on a refinery's expectations about the price path of oil, this could have created an incentive to store gasoline for the next month. Furthermore, because the phasing out of price controls was announced, there was an additional incentive to withhold until prices were free to adjust.

The effect of phasing out price controls on US production is unclear, but there is some evidence that production increased. Figure 8 plots monthly domestic production and includes vertical lines representing the EPCA's passage, which allowed crude prices to increase $10 \%$ per year and the phasing out of price controls. It also includes a lowest smoothed line for each of the three time periods. There was a clear downward trend in US production from 1974 to 1977, when price con- 
trols were at their strictest. While hardly conclusive, there is some evidence that production initially increased in 1977, when EPCA allowed oil prices to increase by $10 \%$ per year. Production fell toward the end of 1978, possibly because oil producers knew price controls would be phased out in 1979. Production then increased after the phase out began, leveled off, but then fell with oil prices in 1986.

\section{B. Demand-Side Policies}

One of the first policies adopted to reduce consumption was a reduction in the speed limit to 55 miles per hour. On January 3, 1974, Nixon signed into law the Emergency Highway Energy Conservation Act (Public Law 93-239) that gave states 60 days to reduce speed limits or lose all federal highway funds. The Act also allotted $\$ 1.5$ billion to finance a new rail system. ${ }^{14}$

The EPCA of 1975, discussed above, also created Corporate Average Fuel Economy Standards (CAFE). The Act set company-level minimum average fuel economy levels for model years starting in 1978, giving regulatory power to the Department of Transportation's National Highway Traffic Safety Administration. CAFE standards were actually a compromise. Congress (and the Ford administration) initially considered taxes on "gas guzzlers." Initial values for the gas guzzler tax would have placed a tax of $\$ 1,000$ on cars with fuel economy below 13 miles per gallon. This was voted down by a 235 to 166 margin. ${ }^{15}$

The standards under CAFE were viewed as much weaker than the proposed gas guzzler taxes and were "not strenuously opposed by the automobile manufacturers." 16 The vote was 306 to 86 . A second reason suggesting why labor unions and automobile manufacturers supported CAFE standards (relative to the gas guzzler tax) was that the two groups factored in the history of postponing the implementation of tailpipe pollution standards when manufacturers argued they were too costly. ${ }^{17}$ In fact, after oil prices fell in the mid-1980s, CAFE standards were relaxed because manufacturers argued they were too costly.

Unlike the price controls extended by the EPCA, CAFE standards continue today. The 2011 standards were 30.2 miles per gallon (mpg) for cars and $24.1 \mathrm{mpg}$ for light-duty trucks and SUVs. Beginning in 2012, CAFE standards changed considerably in the sense that they are now "footprint based." That is, the standard is now vehicle-specific; larger vehicles, measured by the circumference of their wheels, face a lower standard. As a result, it is difficult to know exactly how average fleet 
Table 2

Gas Guzzler Tax Levels and Cutoffs in 1991 and Their Equivalents in 2011

\begin{tabular}{lllr}
\hline 1991 Cutoffs & $\begin{array}{c}1991 \\
\text { Dollars }\end{array}$ & \multicolumn{1}{c}{ “Equivalent” 2011 Cutoffs } & $\begin{array}{c}2011 \\
\text { Dollars }\end{array}$ \\
\hline Between 21.5 mpg \& 22.5 mpg & $\$ 1,000$ & Between 14.5 mpg \& 15.1 mpg & $\$ 660$ \\
Between 20.5 mpg \& 21.5 mpg & $\$ 1,300$ & Between 13.8 mpg \& 14.5 mpg & $\$ 858$ \\
Between 19.5 mpg \& 20.5 mpg & $\$ 1,700$ & Between 13.1 mpg \& 13.8 mpg & $\$ 1,122$ \\
Between 18.5 mpg \& 19.5 mpg & $\$ 2,100$ & Between 12.4 mpg \& 13.1 mpg & $\$ 1,386$ \\
Between 17.5 mpg \& 18.5 mpg & $\$ 2,600$ & Between 11.8 mpg \& 12.4 mpg & $\$ 1,716$ \\
Between 16.5 mpg \& 17.5 mpg & $\$ 3,000$ & Between 11.1 mpg \& 11.8 mpg & $\$ 1,980$ \\
Between 15.5 mpg \& 16.5 mpg & $\$ 3,700$ & Between 10.4 mpg \& 11.1 mpg & $\$ 2,442$ \\
Between 14.5 mpg \& 15.5 mpg & $\$ 4,500$ & Between 9.8 mpg \& 10.4 mpg & $\$ 2,970$ \\
Between 13.5 mpg \& 14.5 mpg & $\$ 5,400$ & Between 9.1 mpg \& 9.8 mpg & $\$ 3,564$ \\
Between 12.5 mpg \& 13.5 mpg & $\$ 6,400$ & Between 8.4 mpg \& 9.1 mpg & $\$ 4,224$ \\
Less than 12.5 & $\$ 7,700$ & Less than 8.4 & $\$ 5,082$ \\
\hline
\end{tabular}

fuel economy will evolve, but the targets for 2012 were $33.3 \mathrm{mpg}$ for cars and 25.4 for light-duty trucks and SUVs.

The Energy Tax Act of 1978 (Public Law 95-618) established gas guzzler taxes. These were much lower than those considered in 1974. The tax began with 1980 model year vehicles and was limited to cars that weighed below 6,000 pounds; light trucks were exempt. Vehicles that were subject to the tax and had a fuel economy between 14 and $15 \mathrm{mpg}$ were taxed at \$200 (\$474 in 2011 dollars), while those with fuel economies below 14 mpg were taxed at $\$ 550$ ( $\$ 1304$ in 2011 dollars). The Act called for these to eventually increase to $\$ 1,800$ and $\$ 3,850$, respectively. ${ }^{18}$ The number of taxed vehicles was extremely low. In 1980, only 11 vehicles were subject to the tax; this increased to 12 vehicles in 1981 and 20 in 1982. ${ }^{19}$

Gas guzzler taxes remain today. The tax rates and fuel economy cutoffs have not changed since 1991. Therefore, inflation and technological progress have eroded their effective tax levels; that is, whether a vehicle is a "gas guzzler" is a relative term that depends on the the level of technology. Table 2 lists the tax levels and cutoffs that were established in 1991. The table also reports the "equivalent" tax levels and cutoffs for 2011. Specifically, I adjust the tax levels to account for inflation. I also calculate the equivalent 1991 fuel economy cutoffs by accounting for technological progress using a rate of $2 \%$ per year, which is broadly consistent with Knittel (2011). For example, a modern-day vehicle whose fuel economy is between $21.5 \mathrm{mpg}$ and 22.5 would be in the same portion of the distribution for fuel economy as a 1991 vehicle whose fuel economy was between $14.5 \mathrm{mpg}$ and $15.1 \mathrm{mpg}$. That 1991 
vehicle would be taxed at $\$ 1,000$, but in today's dollars this is equivalent to a tax of $\$ 660$.

A number of policies were also adopted implicitly or explicitly subsidizing alternative fuels. The Energy Tax Act of 1978, besides creating the gas guzzler taxes, also had a provision that exempted gasoline that was mixed with at least $10 \%$ ethanol from the federal gasoline tax (4 cents at the time). Later, the Alternative Motor Fuels Act of 1988 (Public Law 100-494) gave credits under CAFE to vehicles capable of running on certain alternative fuels. Under the Act, gasoline consumption of a vehicle, for CAFE purposes, is calculated assuming that $50 \%$ of the time the vehicle runs on pure gasoline, while the other $50 \%$ of the time it runs on its alternative fuel. The Automotive Fuel Economy Manufacturing Incentives for Alternative Fueled Vehicles Rule of 2004 extended these credits.

Renewable Fuel Standards-requirements to buy a minimum amount of alternative fuels-began with the Energy Policy Act of 2005 (Public Law 109-58). The Act required sales of alternative fuels which includes, among others, ethanol, methanol, and biodiesel. It required 7.5 billion gallons of alternative fuels to be sold in 2012. The Energy Independence and Security Act (EISA) of 2007 (Public Law 110-140) extended the original Renewable Fuel Standard (RFS), and differentiates fuels based on their lifecycle greenhouse gas emissions. The RFS calls for minimum levels of a variety of "advanced" biofuels-biofuels that achieve large reductions in greenhouse gas emissions relative to gasoline. ${ }^{20}$ Ultimately the current RFS calls for 36 billion gallons of alternative fuels to be sold in 2022.

\section{What Happened to Fuel Consumption?}

Figure 7 illustrates that oil consumption fell drastically during the oil shocks; not until 2000 did oil consumption reach its 1978 level on a per capita basis. In this section, I compare on-road transportation fuel consumed over time and across countries.

Figure 9 plots fuel consumption for on-road use of gasoline and diesel, in gallons of oil equivalent per capita, for a large set of countries over time. Consumption in the United States exceeded all other countries prior to the oil shocks and continues to do so today. At least two patterns emerge. First, Canada appears to have lagged behind the United States in responding to the second oil price shocks. Canada, a net exporter of oil, initially kept prices below those in the United States. 

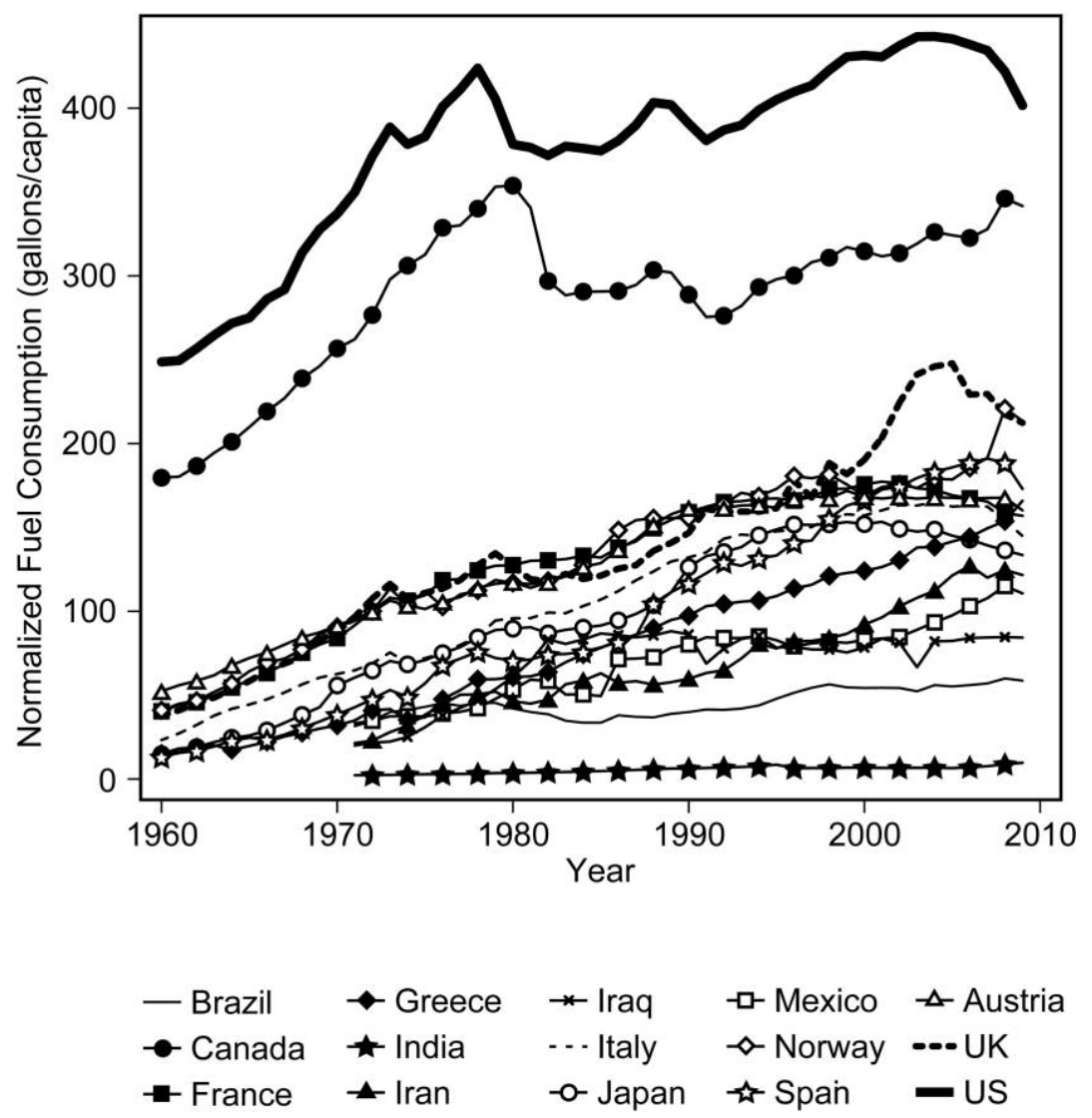

Fig. 9. Gasoline and diesel consumption across countries over time (gallons per capita)

Second, consumption in the European countries responded little to the second price shock. Some European countries effectively smoothed the price shock by reducing fuel taxes. ${ }^{21}$ Both of these points is illustrated in table 3 for a subset of Organisation for Economic Co-operation and Development (OECD) countries. Canadian prices did not respond much in 1978 and 1979, but did in 1980. United Kingdom prices fell in 1978 and didn't increase by nearly as much as prices in Italy, nor did prices in Germany and France. Because US gasoline taxes were so low, changes in crude prices had a larger impact, in percentage terms, on prices.

I next normalize consumption at each country's 1972 level and plot normalized consumption in figure 10. Both the United States and Can- 
Table 3

Percentage Change in Retail Gasoline Price and Taxes as Share of Price, 1970 to 1979

\begin{tabular}{lccccc}
\hline Country & $\begin{array}{c}\text { \% Change in } \\
\text { Price from } \\
\text { 1970 to 1978 }\end{array}$ & $\begin{array}{c}\text { \% Change in } \\
\text { Price from } \\
\text { 1970 to 1978 }\end{array}$ & $\begin{array}{c}\text { Effective } \\
\text { Tax Rate } \\
\text { in 1970 }\end{array}$ & $\begin{array}{c}\text { Effective } \\
\text { Tax Rate } \\
\text { in 1978 }\end{array}$ & $\begin{array}{c}\text { Effective } \\
\text { Tax Rate } \\
\text { in 1979 }\end{array}$ \\
\hline Canada & 1.9 & 3.3 & 82.2 & 59.5 & 47.9 \\
France & 16.3 & 14.3 & 289.5 & 132.5 & 180.0 \\
Germany & 7.7 & 15.2 & 263.5 & 143.1 & 125.7 \\
Italy & 41.8 & 37.4 & 364.3 & 254.7 & 208.9 \\
Japan & -0.3 & 19.5 & 141.8 & 72.5 & 72.0 \\
United & & & & & \\
Kingdom & -15.2 & 16.6 & 257.1 & 71.6 & 46.90 \\
United States & 7.5 & 35.1 & 44.2 & 25.0 & 18.2 \\
\hline
\end{tabular}

Source: Tait and Morgan (1980).

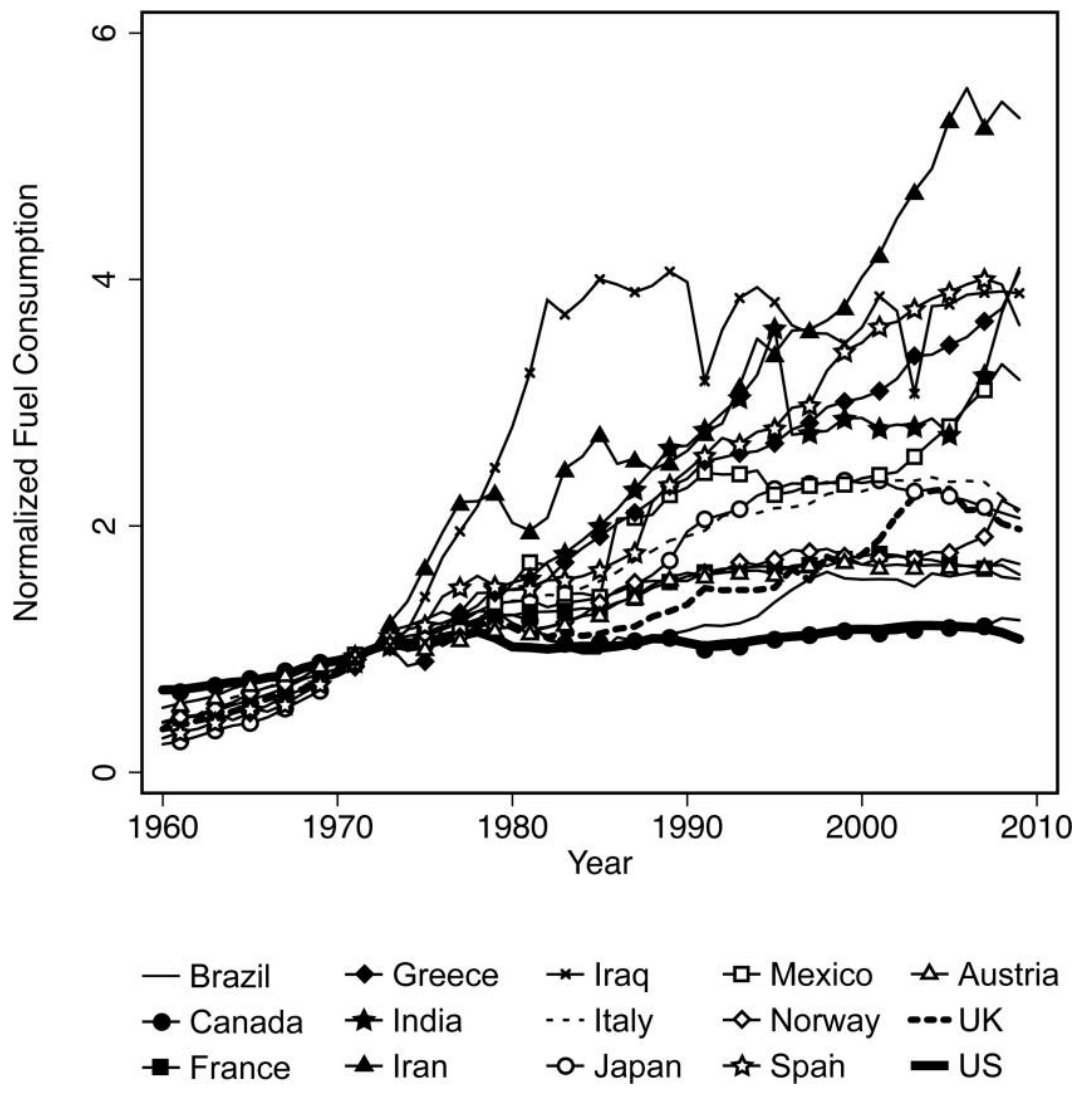

Fig. 10. Normalized gasoline and diesel consumption across countries over time (gallons per capita) 

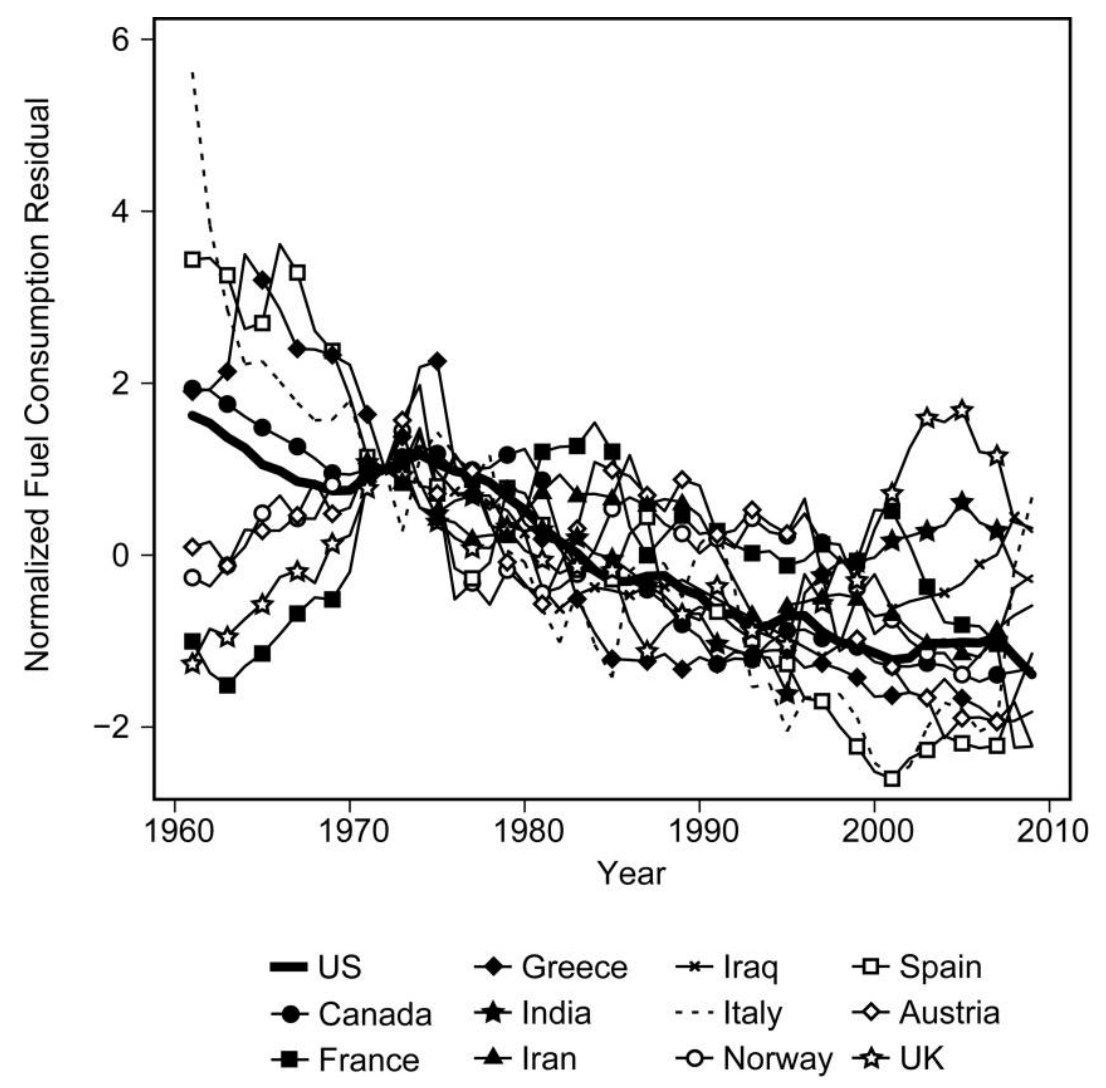

Fig. 11. Normalized gasoline and diesel consumption across countries over time (gallons per capita)

ada exhibited the slowest growth in consumption since 1972. While one may take this as evidence that US and Canadian policies were most effective, it is difficult to distinguish this from a level effect and differences in income growth. The United States and Canada had more room to reduce consumption because the fuel economy of their vehicle stock was so much lower than in other countries. Countries also varied considerably in their income growth over this time period. To control for changes in income, population density, and average year effects, I regress the log of fuel consumption on the log of population density, the $\log$ of GDP, and year- and country-fixed effects. I then normalize the residuals to their 1972 levels. These are plotted in figure $11 .{ }^{22}$ After controlling for changes in GDP and population density, the increase in fuel 
consumption of the United States (and Canada) is toward the middle of the distribution. Therefore, even without accounting for the level effect, it doesn't appear as though the growth in US fuel consumption was low compared to these countries.

\section{Were Gas Taxes on the Table?}

\section{A. The Nixon Administration}

President Nixon was not against gas taxes. In fact, Nixon pushed for gasoline taxes even before the oil embargo. In November of 1970, President Nixon proposed to Congress a modest two to three cents per gallon tax (9 and 14 cents in 2011 dollars, respectively) for leaded gas. The proposal was not in response to concerns about oil imports, but was instead viewed as a revenue generator and a way to promote unleaded gasoline. ${ }^{23}$ The Nixon administration again considered a gasoline tax in 1973. Prior to the embargo, gasoline prices increased from 38.5 cents per gallon in May to over 55 cents in June. Gasoline taxes were considered a way to reduce the shortages generated from the price controls. It was reported that in June of 1973 many of Nixon's advisors supported a tax as high as ten cents per gallon (40 cents in 2011 dollars). ${ }^{24}$ The regressivity of such a tax was frequently noted in newspaper articles and op-eds of the time. For example, a June 6, 1973, New York Times letter to the editors by Carl M. Selinger, Dean of Bard College, entitled "The Immorality of Raising the Gasoline Tax," compared a gasoline tax to a law where "it would be unlawful for any worker with a large family, a low income and other heavy financial obligations to drive his car to work. ... "Foreseeing the large economics literature that would develop as a result of not imposing gasoline taxes, the op-ed did admit that alternatives" may give us a somewhat less efficient society-but that is not an excessive price to pay to keep it a decently just one."

The embargo led to more discussions about the merits of a gas tax. A November 10 New York Times article reports that the administration was considering a 40 cents gasoline tax (\$1.61 in 2011 dollars), with the revenues refunded back to consumers. Nixon's economic advisors supported such a plan, but the Treasury Department opposed it because a refunded tax would be difficult to administer. Such a large tax appears to have been abandoned by the administration, and reports from December of 1973 state that President Nixon pushed for a 10 cents per gallon gasoline tax. ${ }^{25}$ After this met resistance in Congress, the admin- 
istration then floated an idea of taxing "excess" gasoline consumption. According to the plan, families would be allowed to purchase 14 gallons of gasoline tax free for their first car and seven gallons of gasoline tax free for the second car, but this did not appear to gain traction. ${ }^{26}$

\section{B. The Ford Administration}

In contrast to Nixon and despite much support within his administration, President Ford was staunchly against increasing gasoline taxes. He was not, however, against raising the price of gasoline, as he supported tariffs on foreign oil and pushed to decontrol oil prices.

Ford called for a reduction in US oil consumption of one million barrels per day by the end of 1975-roughly a 6\% reduction from 1974 levels. Newspaper articles from November and December of 1974 suggest that many of the president's top energy advisors pushed for a gas tax to meet this goal, despite the unpopularity of such a tax with the public. Secretary of the Interior Rogers C. B. Morton was one of the main proponents, although it was reported that four of Nixon's senior advisors supported such a tax: Morton, Treasury Secretary William E. Simon, Secretary of State Henry Kissinger, Council of Economic Advisors (CEA) chair Alan Greenspan, and Federal Energy administrator John C. Sawhill. ${ }^{27}$ Morton vocally advocated for a 30 cents per gallon tax (\$1.01 in 2011 dollars) with most of the money refunded back to consumers as early as late $1973 .{ }^{28}$ After Ford had publicly ruled out an increase in gasoline taxes in October of 1974, Sawhill appeared on a nationally-televised show outlining a proposal to raise the gasoline tax by 10 to 30 cents with the revenue used to lower income taxes. ${ }^{29}$

In November of 1974, Secretary Morton went on TV supporting a gasoline tax. The next day, the president responded by saying "I thought that others in the executive branch got the word, and I hope this word is conveyed to my good friend, the secretary of the interior. We are not considering an increase in the gasoline tax." ${ }^{130}$ It is widely believed that the public support for a gas tax led to the firing of both Morton and Sawhill. ${ }^{31}$

Ford suggested that his major concerns were the regressivity of such a tax and its large incidence on rural communities. ${ }^{32}$ But, the president also seems to have viewed the idea of taxing a product, but then refunding the revenues from that tax back to consumers, as a logical inconsistency. ${ }^{33}$

According to the Associated Press at the time, the White House was instead considering mileage standards, tax credits for efficient cars, weight 
and horsepower restrictions, rationing, and somewhat ironically, oil tariffs that could turn into taxes on all oil production.

Besides Ford's advisors, other policymakers of the time favored gas taxes. The bipartisan Joint Economic Committee recommended a 30 cents gasoline tax with the estimated $\$ 25$ billion refunded to consumers. To put this in perspective the federal gasoline tax at the time was a mere four cents. Newspaper articles at the time appeared to actively debate the merits. ${ }^{34}$ The arguments in favor of the tax note the smaller transaction costs compared to rationing and equate it to a coupon rationing program with saleable coupons (although changing who captures the rents). The arguments against this focus on regressivity of such a tax and its inflationary effect.

By the end of 1974, President Ford may have left the door slightly open for increases in gasoline taxes. ${ }^{35}$ The New York Times reported that President Ford had his main advisors meet him in Colorado on December 26 to discuss energy policy. The article reports that the president would entertain proposals for a higher gasoline tax. Why the shift? The need for revenue. Congress called for a reduction in income tax rates to ease the recession and Ford viewed a gasoline tax as a way to offset these revenue reductions. ${ }^{36}$ This shift is consistent with Ford not understanding the merits of taxing a product to change marginal incentives while returning the revenues from the tax to consumers.

The door wasn't open for long, as it slammed shut the next day when Ford said of a gasoline tax: "That's about as dead as any option I know. . . . I think there are many better choices." ${ }^{137}$ Ford reiterated this view in his January 1975 State of the Union Address that highlighted his energy plan, stating: "I want you to know that before deciding on my energy conservation program, I considered rationing and higher gasoline taxes as alternatives. In my judgment, neither would achieve the desired results and both would produce unacceptable inequities." In its place, Ford called for mileage standards.

Somewhat counter to such strong opposition to gasoline taxes, in his State of the Union Address, Ford also said that he would use his presidential powers (specifically Section 232 of the Trade Expansion Act of 1962) to impose a $\$ 1$ per barrel tariff on imported oil beginning on February 1, 1975 ( $\$ 3.33$ in 2011 dollars). The tariff would increase to $\$ 2$ on March 1 and $\$ 3$ on April 1. Ford also called for domestic crude prices to be decontrolled. He promised to rescind the tariffs when "broader but necessary legislation is enacted." He went on to say: "To that end, I am requesting the Congress to act within 90 days on a more comprehensive 
energy tax program. It includes: excise taxes and import fees totaling $\$ 2$ per barrel on product imports and on all crude oil; deregulation of new natural gas, and enactment of a natural gas excise tax." Ford's attempts to decontrol oil prices were killed by the House in July of 1975. ${ }^{38}$

How receptive was Congress to a gasoline tax increase or oil taxes? Support for, and opposition against, cut across political parties, although Democrats, on average, appear to have been more favorable. The Senate Democratic leader, Mike Mansfield, stated he was open to higher gasoline taxes:

He would take another look at proposals to raise the federal gasoline tax 'by 10, 20, 25 cents a gallon' if such an increase were proposed by President Ford as part of a balanced package of energy conservation measures.

A number of other key Democratic senators supported gasoline taxes. For example, Lloyd Bentsen, D-Texas, proposed a gasoline tax, to be rebated back to consumers, that would begin at five cents in 1976 and increase to 30 cents per gallon in four years. ${ }^{39}$ The House Democrat's energy plan for 1975 included an increase in the gas tax of 23 cents per gallon. ${ }^{40}$

Other Democrats opposed gasoline taxes. One of the biggest opponents was the Democratic chairman of the Ways and Means Committee, Wilbur D. Mills from Arkansas. In an August 1974 speech to the Southern Farmers Association, Mills stated that if the Ford administration put forth a ten cents gas tax, "he (Ford) would know that as long as I am chairman of the Ways and Means Committee it would not be enacted." 41 Senators Walter Mondale, D-Minnesota and Edmund Muskie, D-Maine were also publicly opposed. Opposition to tax increases appeared to have been based, at least publicly, on the regressive nature of the tax. For example, Representative Peter Peyser, R-New York, and John Brademas, D-Indiana, circulated a letter asking their colleagues to oppose a tax on the grounds that it would "push the already strained working man and working woman past the financial breaking point." 42

\section{Key Stakeholders Response to Gasoline Taxes}

While President Ford seemed to be against gasoline taxes, another Ford supported an increase in gasoline taxes. Henry Ford II recommended a ten cent gasoline tax in November of 1974. His support for such a tax was driven by his desire to use the revenues to help the US auto industry. General Motors and Chrysler initially opposed the idea, but less 
than a month later, the newly appointed chairman of General Motors, Thomas A. Murphy, stated: "If in the judgment of the administration it looks like a gasoline tax is necessary, I think we ought to consider it." 43

Roughly a month of reflection by the automobile industry led to even more support for increased taxes, albeit for petroleum taxes rather than gasoline taxes. The automobile industry understood that higher gasoline prices might carry some benefits because shortages adversely affected sales. A petroleum tax would also broaden the scope of the price increases. The light-duty industry only consumed $28 \%$ of US oil at this time, and much of the oil went to heating and electricity generation.

A December 23, 1974, New York Times article reports:

The automobile industry is moving toward favoring some form of tax on petroleum in the hope of guaranteeing an unregulated and adequate supply of gasoline for its products in the future. The industry also believes that a tax on petroleum, although it would increase gasoline prices and therefore tend to cut car sales and accelerate the trend toward smaller cars, would be less painful than some of the energy conservation measures being considered by Congress and the Ford administration.

While conventional wisdom today seems to be that CAFE standards were favored by US automobile manufacturers at the time, it isn't clear. The same article goes on to say:

Elliott M. Estes, the president of the General Motors Corporation, for example, said in a recent interview that he would favor a tax on imported petroleum, which would lead to high gasoline prices, rather than further government regulations to improve fuel economy on cars.

Henry Ford II also adjusted his position by stating that "another way to accomplish these goals would be to level a general excise tax on petroleum. This might be more effective and equitable and it would certainly generate more revenue." The same article says that Chrysler and American Motors Corporation (AMC) were expected to also support an excise tax, as well as eliminating price controls on "old oil."

Another key group of stakeholders were farmers. While there is some indication that farmers opposed an increase in the gasoline tax (e.g., Mills's speech discussed above), their opposition does not seem to be particularly vocal. Newspaper searches in Google's new archive for "gas tax and farmer/farming/farm" are few. In addition, it is difficult to separate out the farmer effect from the low income effect.

The oil industry does not appear to have been very vocal regarding gasoline or oil taxes, at least publicly. The oil industry was often vilified 
Table 4

Harris Survey Results Related to Gas Taxes, November 1974

\begin{tabular}{lccc}
\hline Question & \% Favor & \% Oppose & \% Not Sure \\
\hline $\begin{array}{l}\text { Unqualified 20 cents tax increase } \\
\text { Unqualified 10 cents tax increase }\end{array}$ & 7 & 88 & 5 \\
$\begin{array}{l}10 \text { cents increase \& tax credit on } \\
\text { income tax }\end{array}$ & 35 & 54 & 13 \\
$\begin{array}{l}10 \text { cents increase if it meant US not } \\
\text { dependent on Arab oil }\end{array}$ & 39 & 47 & 9 \\
$\begin{array}{l}10 \text { cents increase \& tax credit on } \\
\text { income tax \& it meant US not } \\
\text { dependent on Arab oil }\end{array}$ & 51 & 38 & 14 \\
\hline
\end{tabular}

by the public and many policymakers expressed concerns about windfall profits for domestic oil producers resulting from changes in the world price for oil. ${ }^{44}$ Therefore, they may have consciously tried to stay out of public forums. There is also evidence that the threat of further regulation put pressure on oil companies, notably large oil companies, to keep prices for refined products down. (See, Erfle, Pound, and Kalt 1981; and Erfle and McMillan 1990.)

Consumers seemed to have been the biggest opponents of gasoline taxes. Polling at the time suggested that the public supported gas taxes only under certain, and unrealistic, circumstances.

A Harris Survey asked 1,525 households a series of questions on varying the size of the tax, its impact on oil imports, and the use of the revenue. Table 4 summarizes the results. The poll asked consumers if they would support a ten or 20 cents tax increase without any other conditions. Consumers overwhelmingly opposed such a tax. Support increased if either consumers received an income tax credit for the gasoline taxes or the 10 cents tax meant the United States would no longer import oil from the Middle East. ${ }^{45}$ Only if consumers were able to write off tax payments and a 10 cents tax leading the United States to be independent of Middle East oil did a slight majority of those polled support a tax.

Consumers appeared to have preferred other, less efficient ways to reduce consumption. When asked whether they would prefer a tax on gasoline or a tax on large inefficient cars in order to limit gasoline consumption, $70 \%$ of those survey by the Opinion Research Corporation (ORC) Public Opinion Index in December of 1974 preferred a tax on large cars; only $13 \%$ favored a tax on gasoline. ${ }^{46}$

Consumers also preferred rationing over increases in fuel prices. When asked whether they would prefer the country to conserve oil 
through mandatory gasoline rationing on an odd-even basis or an 11cents increase in gasoline prices as a result of an import tariff on oil, $60 \%$ of consumers preferred rationing, $25 \%$ preferred the tariff, with $15 \%$ being undecided. This is a common theme. A similar survey in January of 1975 asked consumers if they prefer Ford's oil tariff (projected to increase gasoline prices by 11 cents) to a nationwide rationing program with the understanding that consumers would not get all of the gasoline they needed. Some $61 \%$ of those surveyed preferred rationing. ${ }^{47}$ A January 1974 New York Times article said the Federal Energy Office was receiving over 2,000 letters and telegrams a day on how to solve the energy crisis. About $90 \%$ of the letters preferred rationing. ${ }^{48}$

Labor unions were also against gasoline taxes. On November 24, 1973, in response to George P. Shultz, Nixon's Secretary of Treasury, arguing in favor of a gasoline tax, the American Federation of Labor and Congress of Industrial Organization (AFL-CIO) asked Congress to block the Nixon administration from increasing gasoline taxes. ${ }^{49}$

\section{Carter Administration}

President Carter pushed for gasoline taxes and oil tariffs throughout his presidency. In his 1977 energy plan, Carter called for an increase in the federal gasoline tax and the decontrol of oil and gasoline prices. Oil prices were still hovering at around $\$ 50$ in real terms; they had been roughly constant from 1974 to 1977. But, price controls on oil and concerns about the level of imports continued efforts to incentivize conservation.

Carter's gasoline tax plan was based on whether the nation's oil consumption exceeded some baseline. Under the plan, if gasoline consumption exceeded the target in 1978, a five cents tax would be imposed. For every percentage point where future consumption exceeded the target, an additional five cents would be added to the tax. The entire tax was capped at 50 cents. ${ }^{50}$ The revenues from the tax would be given back to consumers in the way of tax credits on a per capita basis. ${ }^{51}$

Carter's proposal also called for replacing price controls on crude oil with a tax equal to the difference between the price control and the world price. Again, one of, if not the main motivation behind price controls for domestic oil, was concerns that allowing domestic supplies to get the market price would result in windfall profits for oil companies. A tax equal to the price differences also accomplished this, but because gasoline prices were based on average acquisition costs, Carter's plan 
would increase gasoline prices (and shift rents away from refiners). According to the plan, all domestic prices would increase to the "new" oil price of \$11.28 a barrel (in nominal dollars) in 1979, and old oil would be taxed the difference between the current price control ( $\$ 2.25$ per barrel) and \$11.28. Domestic oil prices for existing resources would continue to be subject to price controls of $\$ 2.25$ and $\$ 11.28$ per barrel for oil and new oil. Newly discovered oil would be allowed to move to the market price over a three-year period. New oil was defined as a well farther than 2.5 miles away from an existing well or 1,000 feet deeper than an existing well if it was within the 2.5 mile radius.

Despite being Democratic-controlled, Congress blocked his attempts. ${ }^{52}$ The main opposition came from rural states and from labor groups. Shortly after his proposal, the president of the Building and Construction Trades Department of the AFL-CIO said: "We must not hit hardest those with the lowest incomes. High gasoline taxes would be a regressive tax on the poor, and there's little evidence that high gasoline prices would promote conservation." ${ }^{\prime 53}$ The president of the International Brotherhood of Teamsters, Frank E. Fitzsimmons, said that it would be "awfully hard on the people who must commute some 20 and 30 miles to work." 54

There was some initial optimism in Congress that such a tax could be passed. Representative Al Ullman, D-Oregon, chairman of the Ways and Means Committee said that: "There's always been strong opposition and always will be. That's just automatic." But, he went on to say, "A gas tax, put together a certain way, with adequate rebates, would be passable." ${ }^{\prime 55}$ Others were more skeptical. Senator William D. Hathaway, D-Maine, said, "The rural states would have a particular problem adjusting to a gas tax increase. ... Past history would indicate it would not have much of a chance of passage in Congress." ${ }^{56}$ By now, many were convinced that the US car culture rendered higher gas taxes a nonstarter. Senator Henry M. Jackson, D-Washington, and chairman of the Energy and Natural Resources Committee, called Carter's gas tax, " just not doable" going on to say: "Right or wrong, we have an automobile culture. The truth is, people are going to continue to buy gasoline because they have to get to work." In 1977 there were 0.67 vehicles per capita compared to over 0.80 today. ${ }^{57}$

Senator Jackson's views seemed to represent those of consumers. A CBS/New York Times survey, taken days after Carter's energy plan was proposed, found that consumers opposed higher gasoline prices by a 62 to 32 margin, and higher oil prices by a 53 to 37 margin. The survey also found that blue-collar families were less likely to favor gas taxes 
than white-collar families. Similar to the current debate about climate change, one source of the lack of support for taxes was that not everyone was convinced that an energy crisis existed. Small-car-driving respondents agreed with Carter on the severity of the energy crisis by a 56 to 38 margin, but only $38 \%$ of large-car-driving respondents agreed. ${ }^{58}$

On June 9, 1977, the Ways and Means Committee voted 27 to 10 against Carter's "stand-by" tax. It also voted 25 to 11 against a three cent tax with the revenues financing public transportation. ${ }^{59}$ There seemed to have been some optimism for the passage of the three cent tax, but members noted that the plan also called for oil taxes that would increase gasoline prices (these were ultimately not adopted, however). ${ }^{60}$ There were a few attempts to revive the gasoline tax over the next few months, but nothing came of them. Ultimately, there was a tax placed on industrial oil use in cases where coal was an option, but no taxes passed that would affect gasoline prices.

The oil and gasoline price landscape changed again in 1979 with the Iranian Revolution. Oil prices began the year below $\$ 50$ a barrel (in 2011 dollars), but began to inch up beginning in May when prices hit $\$ 56$ a barrel. On November 4, 1979, a group of Iranian student revolutionaries took over the US Embassy in Tehran, holding more than 60 Americans hostage. Carter responded by imposing an oil embargo against Iran. Further unrest in Iran shut down oil exports. By the end of the year, prices were roughly $\$ 93$ a barrel. By February of 1980, the price was about $\$ 100$ a barrel. Calls for higher gas taxes began to show up in oped. A New York Times op-ed called for a revenue-neutral \$1 per gallon tax, but admitted that "The American people, most politicians reckon, are less willing to accept a tax on auto power than a tax on mother's milk." ${ }^{\prime \prime 1}$ A month later Robert Stobaugh and Daniel Yergin called for a tax of between 25 and 50 cents. ${ }^{62}$ In December, another op-ed in the New York Times called for a 50 cents tax saying, "America can deploy an oil weapon of its own-a stiff tax that would hold down the demand for gasoline, and whose revenues would be rebated to the public." 63

The fate of a significant gasoline tax appeared to be sealed by 1980, however. Carter officials commented in January of 1980 that Carter had rejected proposals within the White House to increase the gasoline tax by 50 cents. The surprising defeat of Canadian Prime Minister Joe Clark in the House of Commons after his party had tried to increase gasoline taxes was yet another warning of the political ramifications of pushing for gasoline taxes. ${ }^{64}$

In March of 1980, Carter used his presidential powers, as Ford did 
before him, to impose a $\$ 4.62$ per barrel tariff on imported oil to begin on May 15 (\$10.95 in 2011 dollars). The tariff was projected to increase gasoline prices by ten cents ( 24 cents in 2011 dollars). Once again Congress resisted. Both the House and Senate passed legislation to block the tariff. Carter vetoed these attempts. What may have been the final nail in a gasoline tax coffin, the House overrode Carter's veto by a vote of 335 to $34 .{ }^{65}$ The Senate voted the veto down by 68 to $10 .{ }^{66}$ This was the first time since 1952 that a president's veto was overridden despite his party controlling both houses.

Once again the regressivity of the tax was cited. Senator Dale Bumpers, D-Arkansas, was quoted as saying, "It's an elitist policy that says, 'the rich will ride and the poor will walk.'" Others seemed to suggest that they may have supported the tariff if the revenues were used to lower other taxes. Senator Sam Nunn, D-Georgia, who initially voted against the legislation blocking it, but then voted to override the veto, cited no assurances from the White House that they would lower other taxes as the reason for his change of heart. ${ }^{67}$

Polling evidence from the time suggests that Congress was voting with the will of the people; consumers continued to favor rationing over both gasoline taxes or allowing prices to clear the market. A 1977 Cambridge Reports/Research International survey of 1,500 people found that $65 \%$ of people preferred rationing over allowing prices to adjust to $\$ 2$ (nominal prices were roughly 60 cents) as a way of reducing a $25 \%$ shortage in gasoline; only $15 \%$ preferred the market outcome. ${ }^{68}$ This was a steep increase from current prices of roughly 60 cents, but the $\$ 2$ focal point does not appear to have driven these results. In April of 1978, the Gallup Organization conducted a poll asking: "If the consumption of oil and gas is reduced in the United States, which of these two ways would you prefer as a way to achieve this: start a rationing program that would require drivers to reduce the miles they drive by about one-fourth, or raise the tax on gasoline so that a gallon will cost 25 cents more than it currently does?" Some 55\% of those polled favored rationing, while only $25 \%$ favored allowing prices to increase by 25 cents. ${ }^{69}$

Just prior to the long gasoline lines that occurred in the summer of 1979, the Los Angeles Times conducted a survey asking whether higher prices or rationing is the answer to oil and gasoline shortages. ${ }^{70}$ Some $42 \%$ of those polled preferred rationing, with $18 \%$ preferring "some other solution." Only $28 \%$ preferred higher prices. Soon after the long lines, consumers did not appear to have changed their opinion. An ABC 
News-Harris Poll of 1,192 people taken in January of 1980 found that $80 \%$ of consumers were against a 50 cent gasoline tax. In contrast, $70 \%$ of respondents favored odd-even gas rationing, and $65 \%$ felt Congress should pass tougher gasoline rationing legislation. A New York Times poll taken around the same time suggests that there may not have been a strong urban-rural split on this issue. Of the 502 New York City residents polled during December of 1979, 90\% opposed raising gasoline taxes as a way of reducing gasoline demand. Rationing was favored by over $60 \%{ }^{71}$

The comparison of similarly worded questions over time provide a way to measure by how much consumers' attitudes changed. Cambridge Reports/National Omnibus Survey conducted a similar poll (in 1980), to their 1977 poll asking whether consumers would prefer rationing to gasoline prices of $\$ 2$. Two things changed between the polls. First, prices increased to roughly $\$ 1.20$. Second, the negatives of shortage were fresh in consumers' minds. Despite this, $49 \%$ of consumers continued to support rationing, compared to only $25 \%$ that support higher prices. ${ }^{72}$ This was a drop, however, from the $65 \%$ that favored rationing in 1977.

\section{Conclusions}

The oil crises of the 1970s led to a number of policies. Some of theseprice controls and rationing programs - no longer exist. Others, such as CAFE standards, gas guzzler taxes, and alternative fuel mandates, continue today. The economics literature is not short of papers suggesting these policies are much less efficient than Pigouvian taxes. In this paper, I reviewed the public discussions that took place on how to address high oil prices. Gasoline taxes were frequently discussed, even more so than today. Figure 12 shows that the number of New York Times articles containing the phrases "gasoline tax" was much lower during the 2008 run up in gasoline prices, compared to those increases of the 1970s.

While gasoline taxes, and allowing prices to be decontrolled, appear to have been on the table and actively discussed as an alternative to price controls, CAFE standards, gas guzzler taxes, and public support for the efficient policy was lacking.

A frequent argument for why CAFE standards and alternative fuel mandates exist is that these policies hide their true cost. This argument is difficult to reconcile with the public's support for similarly inefficient policies such as price-controls-plus-rationing and gas guzzler 


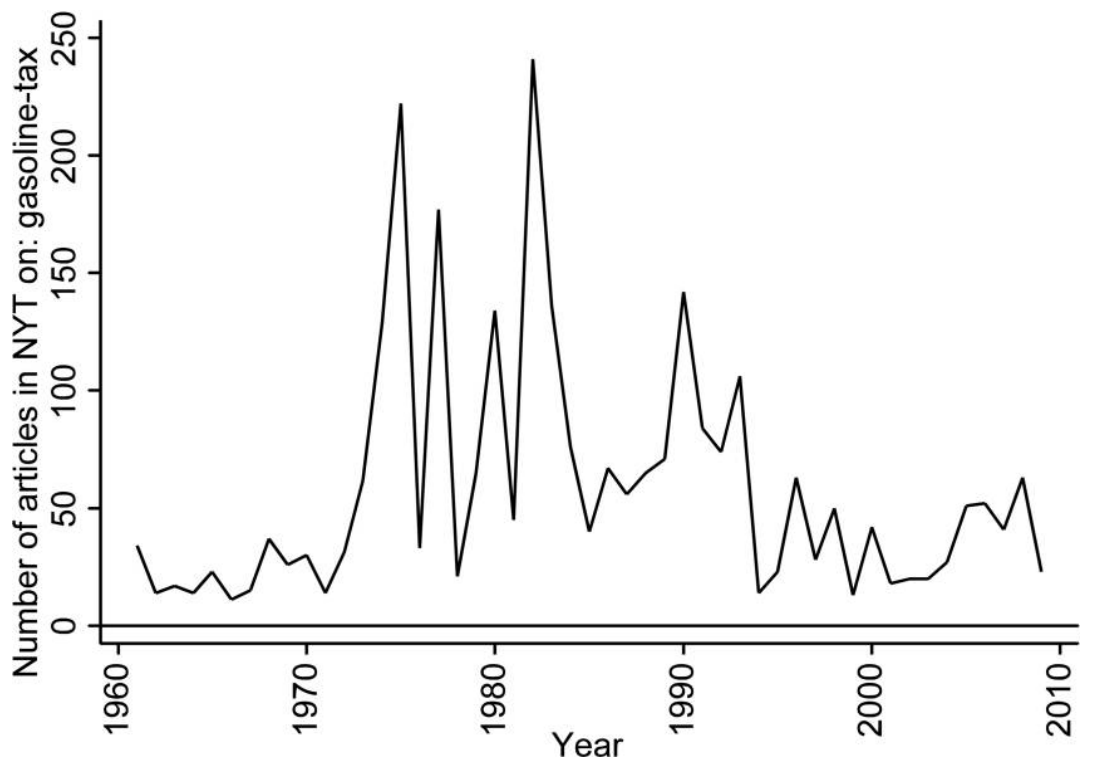

Fig. 12. Number of New York Times articles containing the phrase "gasoline tax" per year

taxes. The costs associated with price-controls-plus-rationing and gas guzzler taxes are certainly salient. Consumers at the time had experienced rationing and long gasoline lines, so would have understood the costs of these policies. Consumers also understood that prices for fuel inefficient vehicles would increase under gas guzzler taxes. What can explain the support? I don't purport to answer this question. Perhaps, economists have overstated the value of people's time, or understated the psychic costs associated with the regressivity of high energy prices. Admittedly, this runs counter to the results in Deacon and Sonstelie (1985) that find when faced with a choice of a zero queue bundled with a high price for gasoline and waiting for a low price, consumers seem to reveal a value of time that is in line with their wage rates.

\section{Endnotes}

This paper has benefited from conversations with Severin Borenstein, Joe Doyle, Ryan Kellogg, Bob Pindyck, Dick Schmalensee, and Jim Sweeney. Financial disclosures: I currently have a grant through the MIT-Ford Motor Company Alliance that is funding a randomized controlled trial in Ford dealerships to determine whether better information about fuel consumption and fuel costs affect consumer purchase behavior. For acknowledgments, sources of research support, and disclosure of the author's material financial relationships, if any, please see http:/ / www.nber.org/chapters/c13055.ack. 
1. Not coincidentally, OPEC was formed in 1960.

2. "Increasing Oil Dependence Viewed as Problem for US," Toledo Blade, April 11, 1972. http:/ /news.google.com/newspapers?id=ZMdOAAAAIBAJ.

3. http://news.google.com/newspapers?id=ynBRAAAAIBAJ\&sjid=Aw8EAAAAIBAJ \&dq=oil-depen $4 \% 2$ C2819373.

4. Tait and Morgan (1980) raised this in 1980. See Knittel (2012) for a more recent discussion of this.

5. However, Ford most often stressed the supply response of decontrolling prices.

6. I freely admit that this runs counter to the results in Deacon and Sonstelie (1985) that find when faced with a choice of a zero queue bundled with a high price for gasoline and waiting for a low price, consumers seem to reveal a value of time that is in line with their wage rates.

7. "Views on Nixon Actions Mixed," Milwaukee Journal, August 16, 1971.

8. The Harris Survey, "Nixon and the Economy," February 3, 1972.

9. For a description, see for example, Mieczkowski (2005).

10. "Ford Signs Bill on Energy that Ends Policy Impasse and Cuts Crude Oil Prices," New York Times, December 23, 1975.

11. http://www.presidency.ucsb.edu/ws/index.php?pid=5452.

12. On a number of occasions House Democrats passed resolutions calling for the extension of price controls, with some members believing the supply for domestic oil was perfectly inelastic. For example Representative Bob Eckhardt, D-Texas, stated that decontrol of oil prices would cost consumers $\$ 1$ billion per month and "won't produce one additional barrel of oil." ("House Democrats Strike a Blow at Carter's Plan for Phasing Out Oil Price Controls," Wall Street Journal, May 23, 1979.) Kathleen O'Reilly, executive director of the Consumer Federation of America, called the decontrol of oil prices "the most inflationary, anticonsumer decision of the century." Other consumer groups, such as the League of Women Voters, the Sierra Group, and the National Audubon Society supported the decision. "Carter Weighs Fuel-Supply Suggestions After Talks with Oil, Consumer Groups," Wall Street Journal, June 4, 1979.

13. "Gasoline Price Controls May be Loosened Further as Refinery-Upgrading Incentive," Wall Street Journal, August 27, 1979.

14. "Nixon Signs Bill to Limit Speeds to 55," Chicago Tribune, January 3, 1974.

15. Democrats voted 131 for and 134 against, while Republicans voted 31 for and 101 against.

16. “House Rejects a Stiff Tax on Low-Gas-Mileage Cars," New York Times, June 13, 1975.

17. "House Rejects a Stiff Tax on Low-Gas-Mileage Cars," New York Times, June 13, 1975.

18. http://www.govtrack.us/congress/bills/95/hr5263.

19. http://www.epa.gov/fueleconomy/guzzler/420b06006.pdf.

20. To date, however, the requirements for these advanced biofuels have been waived.

21. This would seem to be an advantage of higher taxes that is not typically discussed.

22. Japan and Mexico exhibit large fluctuations over this time period. I omit these for visual ease.

23. http://news.google.com/newspapers?id=uJwgAAAAIBAJ\&sjid=JGgFAAAAIBAJ $\& d q=$ gas-tax $\% 20$ nixon\&pg=891\%2C1106559.

24. Cowans, Edward. "Politics, Economics, and the 'Gas' Tax; News Analysis," New York Times June 2, 1973. The article discusses the political difficulties of such a tax. Two examples in particular are that earmarking the revenues would cause problems and that the tax would be regressive. One noted advantage of the tax is that it would cool the economy during a time of economic boon.

25. "Gas Tax Hike Request May Go to Congress from New Energy Head," Rochester Sentinel, December 4, 1973. http://news.google.com/newspapers?id=WDBjAAAAIBAJ \&sjid=A3QNAAAAIBAJ\&dq=gas-tax\%20nixon\&pg=1738\%2C5036574.

26. http://news.google.com/newspapers?id=kcdaAAAAIBAJ\&sjid=BWODAAAAIBAJ $\& d q=$ gas-tax $\% 20$ nixon\&pg $=3504 \% 2$ C 3052299 .

27. Cowan, Edward. "Ford in Conflict With Aides on Higher Gasoline Tax," New York Times November 21, 1974, and Cowan, Edward. "Ford Unlikely to Ask For Quick Action to Save Oil," New York Times, October 4, 1974. 
28. http://news.google.com/newspapers?id=p3hPAAAAIBAJ\&sjid=ggUEAAAAIBAJ $\& d q=$ gas - tax $\% 20$ ford \&pg $=6150 \% 2 \mathrm{C} 2114373$.

29. Young, Robert. "Ford Rejects Gas Tax Hike," Chicago Tribune, October 4, 1974.

30. Cowan, Edward. "Ford in Conflict With Aides on Higher Gasoline Tax," New York Times, November 21, 1974.

31. "Gasoline-Tax Idea Arises Only to Be Killed Again," Wall Street Journal, December 2, 1975 .

32. Cowan, Edward. "Ford in Conflict With Aides on Higher Gasoline Tax," New York Times, November 21, 1974.

33. Cowan, Edward. "Ford Held Unlikely to Ask Quick Action to Save Oil," New York Times, October 4, 1974.

34. See "Is a Gasoline Tax a Better Alternative?," St. Petersburg Times, February 1, 1975, and "It Seems Obvious," St. Petersburg Times, XX, XX 1975. These articles show a debate prompted by the Joint Economic Committee recommendation released on February 1, 1975.

35. "Ford Still Might Go for Tax Hike, Morton says," Chicago Tribune, December 11, 1974.

36. Cowan, Edward. "Ford Calls Aides to Weigh Energy and the Economy," New York Times, December 26, 1974.

37. Beckman, Aldo. "Gasoline Tax Hike is Dead, Ford Says," Chicago Tribune, December 27, 1974.

38. "House Rejects Ford Plan to Decontrol Oil Prices," Toledo Blade, July 23, 1975.

39. "Democrats Study a 'Gas' Tax Keyed to Cut Jobless," New York Times, December 2,1974 .

40. http://news.google.com/newspapers?id=Q68wAAAAIBAJ\&sjid=1PoDAAAAIBAJ \&dq=gas-tax $\% 20$ ford\&pg=1821\%2C 3236594 .

41. New York Times, August 27, 1974.

42. "Ten Cent Gas Tax Unpopular," Lodi News-Sentinel, October 1, 1974.

43. "GM Would Back Gasoline Tax Rise," New York Times, December 3, 1974.

44. Smith (1982) finds that the price control system led to large transfers from oil producers to refiners (often the same company), but not to consumers.

45. The exact question was: "Would you favor or oppose a ten-cent-a-gallon increase in the federal tax on gasoline if people received a tax credit on those taxes that they paid in their next year's income tax?"

46. A total of 604 telephone interviews were made. The exact question was: "In order to limit the use of gasoline by large cars or engines that get low gas mileage, which do you think would be better- $\mathrm{a}$ tax on gasoline or an extra tax on these large cars at the time of purchase?" ORC Public Opinion Index, December 1974. Retrieved Dec. 19, 2012, from the iPOLL Databank, The Roper Center for Public Opinion Research, University of Connecticut.

47. The exact question was: "There has been quite a lot of controversy regarding some of the president's (Ford's) recommendations on the economy and the energy situation. Which plan do you personally favor for cutting down on gasoline usage: President Ford's plan to impose taxes that would result in higher gasoline prices, or a nationwide rationing program, even if it meant you couldn't get all of the gasoline you needed?" Survey by Time. Methodology: Conducted by Yankelovich, Skelly \& White during January, 1975, and based on 1,046 telephone interviews. Sample: National adult [USYANK.758430.Q06A].

48. "Energy Office Flooded by Suggestions, with 90\% Preferring Rationing," New York Times, January 7, 1974.

49. "The Hot Scoop on Gas Rationing," Chicago Tribune, January 9, 1974.

50. "Text of Fact Sheet on the President's Program Issued by White House Energy Staff," New York Times, April 21, 1977.

51. "Transcript of the President's News Conference on Foreign and Domestic Matters," New York Times, April 23, 1977.

52. From 1977 to 1979 the makeup of the Senate was 61 Democrats, with 38 Republicans and one Independent. The House had 292 Democrats and 143 Republicans. During the second half of his presidency, there were 58 Democrats in the Senate (41 Republicans and one Independent) and 277 Democrats in the House with 158 Republicans.

53. Tolchin, Martin. "Carter's Plan to Raise Gasoline Prices Runs into Opposition," New York Times, April 19, 1977. 
54. "Fitzsimmons Cool on 'Gas' Tax," New York Times, April 24, 1977.

55. Tolchin, Martin. "Carter's Plan to Raise Gasoline Prices Runs into Opposition," New York Times, April 19, 1977.

56. Tolchin, Martin. "Carter's Plan to Raise Gasoline Prices Runs into Opposition," New York Times, April 19, 1977.

57. "Senator Calls Energy Plan 'Not Do-Able' Politically," New York Times, May 2, 1977.

58. Reinhold, Robert. "Survey Indicates President Faces Skepticism Over Energy Program," New York Times, April 29, 1977.

59. Cowan, Edward. "House Panel Rejects Rise in Gasoline Tax," New York Times, June 10, 1977.

60. Cowan, Edward. "House Panel Rejects Rise in Gasoline Tax," New York Times, June 10, 1977.

61. "A Gas Tax or Deeper Trouble Still," New York Times, October 17, 1979.

62. "Beyond the Embargo," New York Times, November 17, 1979.

63. "America's Oil Weapon," New York Times, December 16, 1979.

64. Tolchin, Martin. "Oil Import Fee Dies as Senate Overrides Carter by 68 to 10," New York Times, June 6, 1980.

65. "House, by 335 to 34, Overrides Carter on Oil Import Fee" New York Times, June 6, 1980.

66. "Oil Import Fee Dies as Senate Overrides Carter by 68 to 10," New York Times, June 6, 1980.

67. When Carter imposed the tariffs he said that he would keep the revenues in reserve as a "margin of safety." New York Times, March 15, 1980.

68. The exact question was: "Some energy experts say that our nation has to cut its gasoline usage by $25 \%$. To do this we could either have rationing-in which case you would get three-quarters of gasoline you now use-or we could raise gasoline cost $\$ 2$ per gallon; consumption would go down $25 \%$. Which would you prefer if you had to choose one or the other-rationing where you would get three-quarters of what you use now or gasoline at a price of \$2 per gallon?" Cambridge Reports/National Omnibus Survey, October 1977. Retrieved December 20, 2012, from the iPOLL Databank, The Roper Center for Public Opinion Research, University of Connecticut. http://www.ropercenter.uconn .edu/data_access/ipoll/ipoll.html.

69. Gallup Poll (AIPO), March 1978. Retrieved December 20, 2012, from the iPOLL Databank, The Roper Center for Public Opinion Research, University of Connecticut. http:/ / www.ropercenter.uconn.edu/data_access/ipoll/ipoll.html.

70. The exact question was: "President Carter has announced that he will soon begin to remove price controls from crude oil produced in the United States in order to stimulate oil exploration and to force people to use less oil and gas. Do you think higher prices are the answer to oil and gas shortages, or would you prefer gasoline rationing?" Los Angeles Times poll, May, 1979. Retrieved December 20, 2012, from the iPOLL Databank, The Roper Center for Public Opinion Research, University of Connecticut. http://www.ropercenter .uconn.edu/data_access/ipoll/ipoll.html.

71. “60\% in a Poll Back Gas Rationing," New York Times, January 7, 1980.

72. The exact wording was: "Some energy experts say that our nation has to cut its gasoline usage by $25 \%$. To do this, we could either have rationing-in which case you would get three-quarters of the gasoline you now use-or we could raise gasoline prices enough to discourage consumption. Experts think if gasoline prices rose to $\$ 2$ per gallon, consumption would go down $25 \%$. Which would you prefer if you had to choose one or the other-rationing, where you would get three-quarters of what you use now, or gasoline at a price of $\$ 2$ per gallon?"

\section{References}

Deacon, Robert T., and Jon Sonstelie. 1985. "Rationing by Waiting and the Value of Time: Results from a Natural Experiment." Iournal of Political Economu 93 (4): $627-47$. 
Erfle, S., J. Pound, and J. Kalt. 1981. "The Use of Political Pressure as a Policy Tool During the 1979 Oil Supply Crisis." Discussion Paper \#E-80-09, Kennedy School of Government, Cambridge, MA.

Erfle, Stephen, and Henry McMillan. 1990. "Media, Political Pressure, and the Firm: The Case of Petroleum Pricing in the Late 1970s." The Ouarterly Iournal of Economics 105 (1): 115-34.

Fischer, C., W. Harrington, and I. W. H. Parry. 1982. “Do Market Failures Justify Tightening Corporate Average Fuel Economy (CAFE) Standards?" The Energy Journal 28 (4): 1-30.

Holland, Stephen P., Jonathan E. Hughes, and Christopher R. Knittel. 2009. "Greenhouse Gas Reductions under Low Carbon Fuel Standards?" American Economic Journal: Economic Policy 1 (1): 106-46.

Holland, Stephen P., Jonathan E. Hughes, Nathan Parker, and Christopher R. Knittel. Forthcoming. "Some Inconvenient Truths About Climate Change Policy: The Distributional Impacts of Transportation Policies," The Review of Economics and Statistics.

Jacobsen, Mark. Forthcoming. "Evaluating US Fuel Economy Standards in a Model with Producer and Household Heterogeneity." American Economic Journal: Economic Policy.

Knittel, Christopher R. 2011. "Automobiles on Steroids: Product Attribute Tradeoffs and Technological Progress in the Automobile Sector." American Economic Review 101 (7): 3368-99.

- 2012. "Reducing Petroleum Consumption from Transportation." Iournal of Economic Perspectives 26 (1): 93-118.

Mieczkowski, Yanek. 2005. Gerald Ford and the Challenges of the 1970s. Lexington, KY: University Press of Kentucky.

Sallee, James M. 2011. "The Taxation of Fuel Economy." In Tax Policy and the Economy, vol. 25, edited by Jeffrey R. Brown, 1-37. Chicago: University of Chicago Press.

Smith, Rodney T. 1982. "An Economic Analysis of Income Growth by US Oil Firms: The Roles of US Oil Regulation and OPEC." The Iournal of Business 55 (4): 427-78.

Tait, Alan A., and David R. Morgan. 1980. "Gasoline Taxation in Selected OECD Countries, 1970-79." Staff Papers_International Monetary Fund 27 (2): 349-79.

Verleger, Philip K. 1979. "The US Petroleum Crisis of 1979." Brookings Papers on Economic Activity 1979 (2): 463-76. 


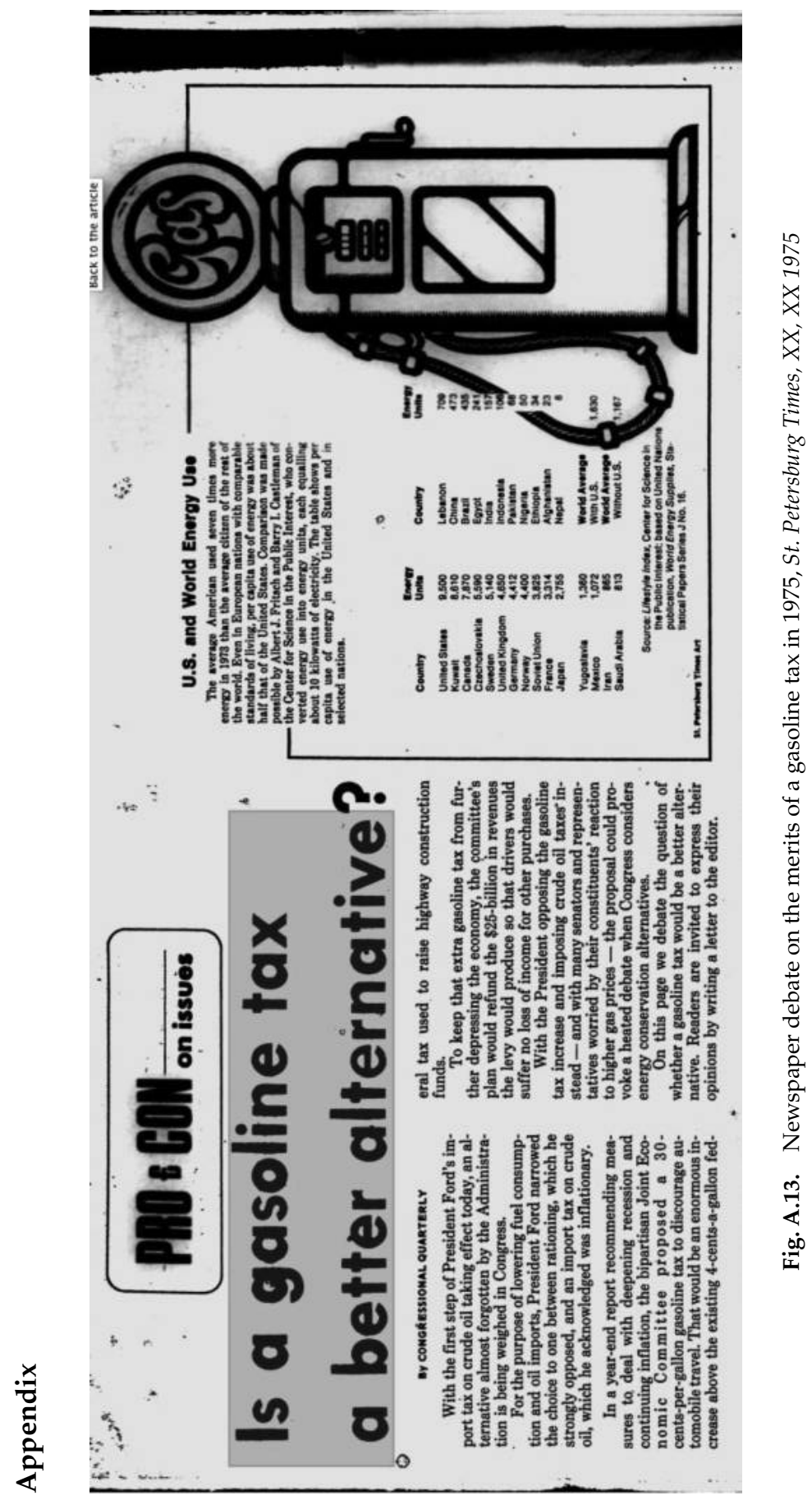

This content downloaded from 018.051.000.096 on February 19, 2019 08:58:44 AM All use subject to University of Chicago Press Terms and Conditions (http://www.journals.uchicago.edu/t-and-c). 


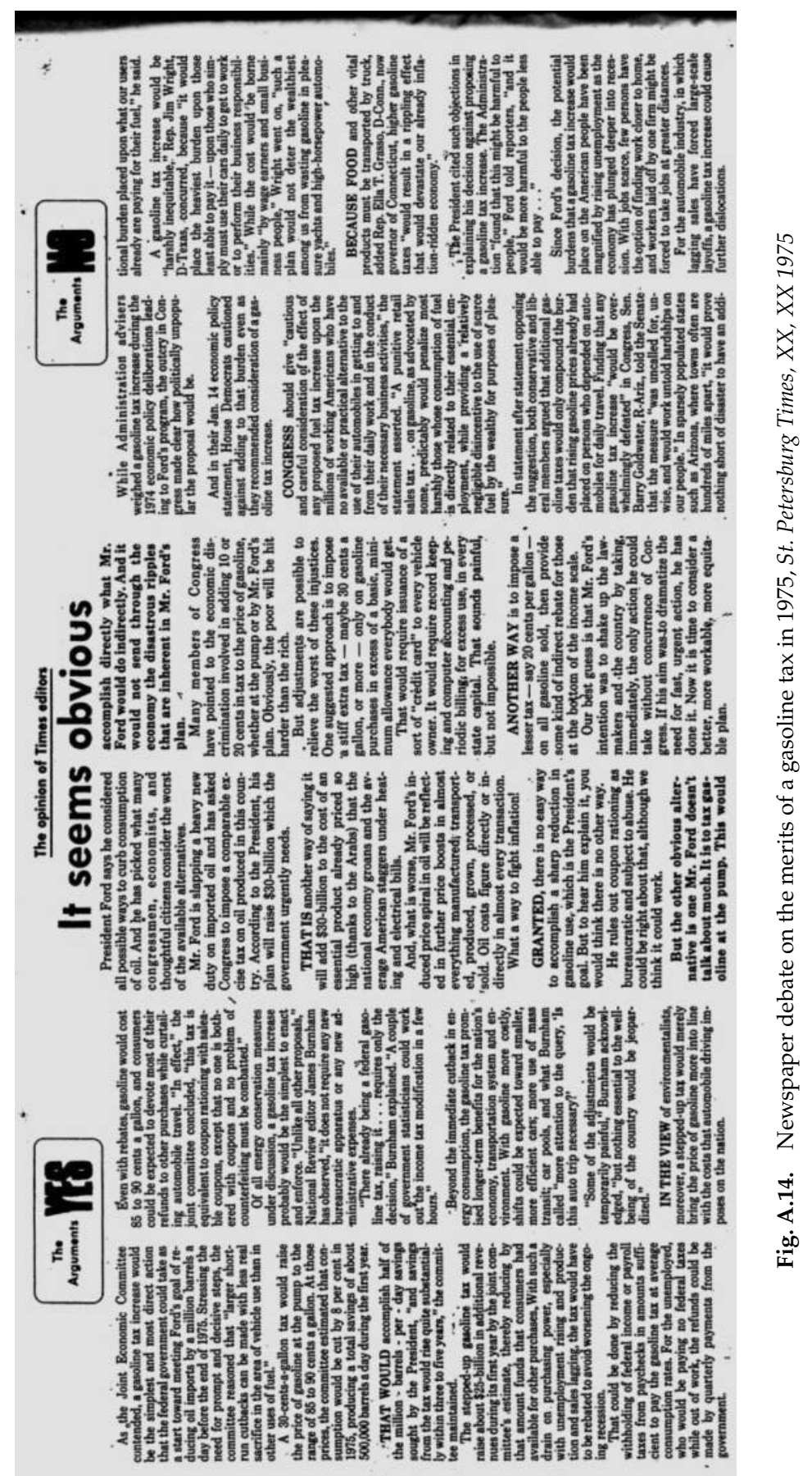

